NBER WORKING PAPER SERIES

THE LONG-TERM EFFECTS OF AFRICA'S SLAVE TRADES

\author{
Nathan Nunn \\ Working Paper 13367 \\ http://www.nber.org/papers/w13367 \\ NATIONAL BUREAU OF ECONOMIC RESEARCH \\ 1050 Massachusetts Avenue \\ Cambridge, MA 02138 \\ September 2007
}

A previous version of this paper was circulated under the title "Slavery, Institutional Development, and Long-Run Growth in Africa". I thank Daron Acemoglu, Robert Bates, Albert Berry, Loren Brandt, Jon Cohen, Bill Easterly, Stanley Engerman, Azim Essaji, Joseph Inikori, Martin Klein, Pat Manning, Ted Miguel, Jim Robinson, Aloysius Siow, Ken Sokoloff, Dan Trefler, Chris Udry, Jeffrey Williamson, and seminar participants at the University of British Columbia, University of California Los Angeles, University of California San Diego, Harvard University, University of Michigan, New York University, Pennsylvania State University, University of Rochester, University of Southern California, University of Toronto, York University, the CIFAR, SED Conference, CEA Meetings, SSHA Meetings, ITAM Summer Camp in Macroeconomics, IEHC, NBER, and WGAPE meetings for valuable comments and suggestions. I thank Maira Avila and Ken Jackson for excellent research assistance., The views expressed herein are those of the author(s) and do not necessarily reflect the views of the National Bureau of Economic Research.

(C) 2007 by Nathan Nunn. All rights reserved. Short sections of text, not to exceed two paragraphs, may be quoted without explicit permission provided that full credit, including $\odot$ notice, is given to the source. 
The Long-Term Effects of Africa's Slave Trades

Nathan Nunn

NBER Working Paper No. 13367

September 2007

JEL No. F1,F15,N0,O1

\begin{abstract}
$\underline{\text { ABSTRACT }}$
Can part of Africa's current underdevelopment be explained by its slave trades? To explore this question, I use data from shipping records and historical documents reporting slave ethnicities to construct estimates of the number of slaves exported from each country during Africa's slave trades. I find a robust negative relationship between the number of slaves exported from a country and current economic performance. To better understand if the relationship is causal, I examine the historical evidence on selection into the slave trades, and use instrumental variables. Together the evidence suggests that the slave trades have had an adverse effect on economic development.
\end{abstract}

Nathan Nunn

Department of Economics

Harvard University

and NBER

1805 Cambridge Street

Cambridge, MA 02138

nnunn@fas.harvard.edu 


\title{
THE LONG-TERM EFFECTS OF AFRICA'S SLAVE TRADES*
}

\author{
NATHAN NUnN
}

Can part of Africa's current underdevelopment be explained by its slave trades? To explore this question, I use data from shipping records and historical documents reporting slave ethnicities to construct estimates of the number of slaves exported from each country during Africa's slave trades. I find a robust negative relationship between the number of slaves exported from a country and current economic performance. To better understand if the relationship is causal, I examine the historical evidence on selection into the slave trades, and use instrumental variables. Together the evidence suggests that the slave trades have had an adverse effect on economic development.

\section{INTRODUCTION}

Africa's economic performance in the second half of the twentieth century has been poor. One, often informal, explanation for Africa's underdevelopment is its history of extraction, characterized by two events: the slave trades and colonialism. Bairoch [1993, p. 8] writes that "there is no doubt that a large number of negative structural features of the process of economic underdevelopment have historical roots going back to European

${ }^{*}$ A previous version of this paper was circulated under the title "Slavery, Institutional Development, and Long-Run Growth in Africa". I am grateful to the editor Edward Glaeser and three anonymous referees for comments that substantially improved this paper. I also thank Daron Acemoglu, Robert Bates, Albert Berry, Loren Brandt, Jon Cohen, Bill Easterly, Stanley Engerman, Azim Essaji, Joseph Inikori, Martin Klein, Pat Manning, Ted Miguel, Jim Robinson, Aloysius Siow, Ken Sokoloff, Dan Trefler, Chris Udry, Jeffrey Williamson, and seminar participants at the University of British Columbia, University of California Los Angeles, University of California San Diego, Harvard University, University of Michigan, New York University, Pennsylvania State University, University of Rochester, University of Southern California, University of Toronto, York University, the CIFAR, SED Conference, CEA Meetings, SSHA Meetings, ITAM Summer Camp in Macroeconomics, IEHC, NBER, and WGAPE meetings for valuable comments and suggestions. I thank Maira Avila and Ken Jackson for excellent research assistance. 
colonization." Manning [1990, p. 124] echoes Bairoch, but focuses on the slave trades, writing: "Slavery was corruption: it involved theft, bribery, and exercise of brute force as well as ruses. Slavery thus may be seen as one source of precolonial origins for modern corruption."

Recent empirical studies suggest that Africa's history can explain part of its current underdevelopment. These studies focus on the link between countries' colonial experience and current economic development [Bertocchi and Canova, 2002; Englebert, 2000a,b; Grier, 1999; Lange, 2004; Acemoglu et al., 2001, 2002]. However, the other important event in Africa's history, its slave trades, has yet to be examined empirically. There are reasons to expect that the slave trades may be at least as important as official colonial rule for Africa's development. For a period of nearly 500 years, from 1400 to 1900, the African continent simultaneously experienced four slave trades. By comparison, official colonial rule lasted from 1885 to about 1960, a total of approximately 75 years.

This paper provides the first empirical examination of the importance of Africa's slave trades in shaping subsequent economic development. In doing this, I construct measures of the number of slaves exported from each country in Africa, in each century between 1400 and 1900. The estimates are constructed by combining data from ship records on the number of slaves shipped from each African port or region with data from a variety of historical documents that report the ethnic identities of slaves that were shipped from Africa. I find a robust negative relationship between the number of slaves exported from each country and subsequent economic performance. The African countries that are the poorest today are the ones from which the most slaves were taken.

This finding cannot be taken as conclusive evidence that the slave trades caused differences in subsequent economic development. An alternative explanation that is just as plausible is that countries that were initially the most economically and socially underdeveloped selected into the slave trades, and these countries continue to be the most underdeveloped today. In other words, the slave trades may be correlated with unobserved country characteristics, resulting in biased estimates of the effect of the slave trades on economic development.

I pursue a number of strategies to better understand the reason behind the relationship between slave exports and current economic performance. First, I review the evidence from African historians on the nature of selection into the slave trades. I also use historic data on pre-slave trade population densities to examine whether it was the less developed parts of Africa that selected into the slave trades. Both sources of evidence show that it was 
actually the most developed areas of Africa that tended to select into the slave trades. I discuss the reason behind this seemingly paradoxical relationship in detail. Second, I use instruments to estimate the causal effect of the slave trades on subsequent economic development. The instruments are the sailing distances from each country to the nearest location of demand for slave labor in each of the four slave trades. Like the OLS coefficients, the IV coefficients are negative and significant, suggesting that increased extraction during the slave trades caused worse subsequent economic performance.

I then explore the precise channel of causality underlying the relationship between slave exports and economic development. Using historical evidence as a guide, I examine whether the procurement of slaves through internal warfare, raiding, and kidnapping resulted in subsequent state collapse and ethnic fractionalization. I find that the data are consistent with these channels.

These findings complement the research of Engerman and Sokoloff [1997, 2002], which shows that slavery in the New World resulted in the evolution of institutions that were not conducive for economic growth. ${ }^{1}$ My results show that not only was the use of slaves detrimental for a society, but the production of slaves, which occurred through domestic warfare, raiding, and kidnapping, also had negative impacts on subsequent development.

The paper is structured as follows. In the following section, I provide an description of Africa's slave trades, providing a detailed historical overview of the manner in which slaves were procured, and the resulting adverse effects. In Section III, I describe the construction of the slave export figures. Section IV documents the correlations that exist in the data, and Section V turns to the issue of causality. In Section VI, guided by the historical evidence, I examine the potential channels of causality. Section VII concludes.

\section{HistoricAl BACKGRound}

Between 1400 and 1900, the African continent experienced four simultaneous slave trades. The largest and most well-known is the trans-Atlantic slave trade where, beginning in the 15th century, slaves were shipped from West Africa, West Central Africa and Eastern Africa to the European colonies in the New World. The three other slave trades - the trans-Saharan, Red Sea, and Indian Ocean slave trades - are much older and predate the transAtlantic slave trade. During the trans-Saharan slave trade, slaves were taken from south of the Saharan desert to Northern Africa. In the Red Sea slave

\footnotetext{
${ }^{1}$ Also see Lagerlöf [2005] and Mitchener and McLean [2003] for related evidence.
} 
trade, slaves were taken from inland of the Red Sea and shipped to the Middle East and India. In the Indian Ocean slave trade, slaves were taken from Eastern Africa and shipped either to the Middle East and India or to plantation islands in the Indian Ocean.

A number of characteristics of Africa's slave trades make them distinct from previous slave trades. First, the total volume of slaves traded was unprecedented. During the trans-Atlantic slave trade alone, approximately 12 million slaves were exported from Africa. Another 6 million were exported in the other three slave trades. These figures do not include those who were killed during the raids or those who died on their journey to the coast. The total effect of the slave trades, according to calculations by Patrick Manning [1990, p. 171], was that by 1850 Africa's population was only half of what it would have been had the slave trades not taken place.

Africa's slave trades were also unique because, unlike previous slave trades, individuals of the same or similar ethnicities enslaved one another. This had particularly detrimental consequences, including social and ethnic fragmentation, political instability and a weakening of states, and the corruption of judicial institutions.

The most common manner in which slaves were taken was through villages or states raiding one another [Lovejoy, 1994; Northrup, 1978]. Where groups of villages had previously developed into larger scale village federations, relations between the villages tended to turn hostile [e.g., Inikori, 2000; Hubbell, 2001; Azevedo, 1982]. As a result, ties between villages were weakened, which in turn impeded the formation of larger communities and broader ethnic identities. Kusimba [2004, p. 66] writes that "insecurity confined people within ethnic boundaries constructing spheres of interaction". Because of this process, the slave trades may be an important factor explaining Africa's high level of ethnic fractionalization today. This is significant for economic development given the established relationship between ethnic fractionalization and long-term economic growth [Easterly and Levine, 1997].

Because of the environment of uncertainty and insecurity at the time, individuals required weapons, such as iron knives, spears, swords or firearms, to defend themselves. These weapons could be obtained from Europeans in exchange for slaves, which were often obtained through local kidnappings. This further perpetuated the slave trade and the insecurity that it caused, which in turn further increased the need to enslave others to protect oneself [Mahadi, 1992; Hawthorne, 1999, pp. 108-109]. Historians have named this vicious cycle the 'gun-slave cycle' [e.g., Lovejoy, 2000] or the 'iron-slave cycle' [e.g., Hawthorne, 2003]. The result of this vicious cycle was that 
communities not only raided other communities for slaves, but also members of a community raided and kidnapped others within the community. Welldocumented examples come from the Balanta of modern day Guinea-Bissau, the Minyanka of modern day Mali [Klein, 2001], and the Makua, Chikunda, and Yao of East Central Africa [Isaacman, 1989, p. 191-192, 196; Alpers, 1969, pp. 413-414; Alpers, 1975, p. 225].

Generally, the consequence of internal conflict was increased political instability and in many cases the collapse of pre-existing forms of government [Lovejoy, 2000, pp. 68-70]. In 16th century Northern Senegambia, the Portuguese slave trade was a key factor leading to the eventual disintegration of the Joloff Confederation, which was replaced by the much smaller kingdoms of Waalo, Kajoor, Baol, Siin and Saalum. Further south, in Southern Senegambia, the same pattern is observed. Prior to the slave trades, complex state systems were in the process of evolving. However, this evolution stagnated soon after the arrival of the Portuguese in the 15th century [Barry, 1998, pp. 36-59]. Similar patterns of instability have also been documented in Eastern Africa [e.g., Isaacman, 1989; Mbajedwe, 2000]. In the late 19th century, the slave trades resulted in the disintegration of the Shambaa kingdom, Gweno kingdom, and Pare states in East Africa's Pangani valley [Kimambo, 1989, p. 247; Mbajedwe, 2000, p. 341-342].

The most dramatic example may be the Kongo Kingdom of West Central Africa. As early as 1514, the kidnapping of local Kongo citizens for sale to the Portuguese had become rampant, threatening social order and the King's authority. In 1526, Affonso, King of Kongo, wrote to Portugal complaining that "there are many traders in all corners of the country. They bring ruin to the country. Every day people are enslaved and kidnapped, even nobles, even members of the king's own family." [Vansina, 1966, p. 52]. This breakdown of law and order was partly responsible for the weakening and eventual fall of the once powerful state [Inikori, 2003]. For many of the other Bantu speaking ethnicities, stable states also existed in earlier periods, but by the time the slave trades were brought to an end few ancient states remained [Colson, 1969, pp. 36-37].

Pre-existing governance structures were generally replaced by small bands of slave raiders, controlled by an established ruler or warlord. However, these bands were generally unable to develop into large, stable states. Colson $[1969$, p. 35] writes that "both the bands and the new states they created retained an air of improvisation. Few band leaders were able to hand power to a legitimate successor. Even where a band leader had become the ruler of a state, succession remained a problem. Leadership was a personal role, rather than an established office." 
The slave trades also contributed to political instability by causing the corruption of previous established legal structures. In many cases, it became common to obtain slaves by falsely accusing others of witchcraft or other crimes [Lovejoy, 2000; Northrup, 1978; Koelle, 1854]. Klein [2001, p. 59] writes that "communities began enslaving their own. Judicial penalties that formerly had taken the form of beatings, payment of compensation or exile, for example, were now converted to enslavement." Often, leaders themselves supported or even instigated this abuse of the judicial system [Mahadi, 1992; Klein, 2001; Hawthorne, 1999, 2003]. To protect themselves and their community from being raided, leaders often chose to pay slaves as tribute, which were often obtained through the judicial system. Hawthorne [1999, 2003] provides detailed studies of this process among the Cassanga of modern day Guinea Bissau. The chief of the Cassanga used the 'red water ordeal' to procure slaves and their possessions. Those accused of a crime were forced to drink a poisonous red liquid. If they vomited, then they were judged to be guilty. If they did not vomit, they were deemed not guilty. However, for those that did not vomit this usually brought death by poisoning. Their possessions were then seized and their family members were sold into slavery.

Evidence from research showing a relationship between a country's history of state development and subsequent economic performance, suggests that these effects of the slave trades may be important for current economic development [Bockstette et al., 2002; Chanda and Putterman, 2005]. Others have argued that Africa's underdevelopment is a direct result of state failure, which stems from Africa's weak and unstable pre-colonial political structures [Herbst, 1997, 2000]. Because Africa's slaves trades were an important factor affecting political underdevelopment, they may be a central reason behind Africa's weak states today.

\section{Slave Export Data}

Because I am interested in examining the effects of the slave trades that resulted because of the procurement of slaves, my measure of interest is the total number of slaves taken from each country during the four slave trades between 1400 and $1900 .^{2}$

I use two types of data to construct the slave export estimates. The first are data that report the total number of slaves exported from each port or region in Africa. I refer to these as shipping data. For the trans-Atlantic slave

\footnotetext{
${ }^{2}$ Ideally, I would also like to include people that entered into local domestic slavery. However, the necessary data to construct these estimates do not exist.
} 
trade, the data are from the updated version of the Trans-Atlantic Slave Trade Database constructed by Eltis et al. [1999]. The database records information for 34,584 voyages from 1514 to 1866. The shipping data are originally from various documents and records located around the world. Because in most European ports, merchants were required to register their ships and declare the volume and value of goods transported, for each ship and voyage, typically, there exists a number of different registers and documents. In the database, $77 \%$ of the trans-Atlantic slave voyages after 1700 have shipping information from more than one source, while the average number of sources for each voyage is six. It is estimated that the database contains $82 \%$ of all trans-Atlantic slaving voyages ever attempted [Eltis and Richardson, forthcoming].

Data for the early period of the Atlantic slave trade not covered by the Trans-Atlantic Slave Trade Database are from Elbl [1997]. For the Indian Ocean, Red Sea, and trans-Saharan slave trades, data are from Austen [1979, 1988, 1992]. The data are based on estimates from all available documents, records and accounts by observers and government officials on the location and volume of slaves exports.

With the shipping data one can calculate the number of slaves that were shipped from each coastal country. However, this does not give an accurate indication of where slaves were originally captured. Slaves shipped from the ports of a coastal country may have come from a country located further inland. To estimate the number of slaves shipped from the coast that came from inland countries, I also use a second source of data that reports the ethnic identity of slaves shipped from Africa. This information comes from a variety of sources such as records of sale, slave registers, slave runaway notices, court records, church records, and notarial documents.

There were a number of ways of identifying the ethnicity or 'nation' of a slave. The easiest was often by a slaves name. Slaves were often given a Christian first name and a surname that identified their ethnicity [e.g., Tardieu, 2001]. As well, a slave's ethnicity could often be determined from ethnic markings, such as cuts, scars, hairstyles, or the filing of teeth [Karasch, 1987, pp. 4-9]. Oldendorp [1777, p. 169] writes that "the people of all Negro nations are marked with certain cuts on the skin. As far as I have been able to learn from the Negroes themselves, these serve to distinguish one nation from another."

Because slaves were legally defined as property, those engaged in the buying and selling of slaves had a strong incentive to correctly identify the birthplace or 'nation' of slaves [Wax, 1973]. Moreno Fraginals [1977, p. 190] writes that "the slave trade was the business that involved the greatest 
amount of capital investment in the world during the eighteenth and nineteenth centuries. And a business of this size would never have kept up a classificatory scheme had it not been meaningful (in overall general terms, in keeping with reality) in designating in a very precise way the merchandise that was being traded."

Information on the ethnicities of slaves shipped during the trans-Atlantic slave trade come from 54 different samples, totalling 80,656 slaves, with 229 distinct ethnic designations reported. Table I summarizes information about the samples used in the trans-Atlantic slave trade. The table reports the location, years covered, number of slaves, and the number of ethnicities that could be identified for each sample. Similar tables for the other three slave trades are reported in Nunn [2007].

The ethnicity data for the Indian Ocean slave trade come from six samples, with a total of 21,048 slaves and 80 different ethnicities reported. The data for the Red Sea slave trade are from two samples: one from Jedda, Saudi Arabia and the other from Bombay, India. The samples provide information for 67 slaves, with 32 different reported ethnicities. For the transSaharan slave trade two samples are available: one from Central Sudan and the other from Western Sudan. The samples provide information on the origins of 5,385 slaves, with 23 different ethnicities recorded. The shipping data from Austen [1992] also provides additional information on which caravan slaves were shipped on, the city or town that the caravan originated in, the destination of the caravan, and in some cases the ethnic identity of the slaves being shipped.

To illustrate how I combine the ethnicity data with the shipping data to construct my estimates I use an example, which is shown in Figure I. The figure is a hypothetical map of the western coast of Africa with each square representing a country.

From the shipping data, I first calculate the number of slaves shipped from each coastal country in Africa. In this example 100,000 slaves were shipped from Country A and 150,000 were shipped from Country B. The problem with relying on the shipping data alone is that many of slaves shipped from Country A may have come from Country B, which lies landlocked behind Country A. Then, using the ethnicity data, I calculate the ratio of slaves from each coastal country relative to any landlocked countries located inland of the coastal country, which requires that I map ethnicities to countries and aggregate up to the country level. In practice, this step relied on a great amount of past research by African historians, linguists, and ethnographers. The sources most heavily used are Koelle [1854], Murdock [1959], Curtin [1969], Higman [1984], and Hall [2005]. 
TABLE I

Slave Ethnicity Data for the Trans-Atlantic Slave Trade

\begin{tabular}{|c|c|c|c|c|}
\hline Location & Years & $\begin{array}{l}\text { Num. } \\
\text { Ethnic. }\end{array}$ & $\begin{array}{r}\text { Num. } \\
\text { Obs. }\end{array}$ & Record Type \\
\hline Valencia, Spain & $1482-1516$ & 77 & 2,675 & Crown Records \\
\hline Puebla, Mexico & $1540-1556$ & 14 & 115 & Notarial Records \\
\hline Dominican Republic & $1547-1591$ & 26 & 22 & Records of Sale \\
\hline Peru & $1548-1560$ & 16 & 202 & Records of Sale \\
\hline Mexico & 1549 & 12 & 80 & Plantation Accounts \\
\hline Peru & $1560-1650$ & 30 & 6,754 & Notarial Records \\
\hline Lima, Peru & 1583-1589 & 15 & 288 & Baptism Records \\
\hline Colombia & $1589-1607$ & 9 & 19 & Various Records \\
\hline Mexico & 1600-1699 & 28 & 102 & Records of Sale \\
\hline Dominican Republic & $1610-1696$ & 33 & 55 & Government Records \\
\hline Chile & 1615 & 6 & 141 & Sales Records \\
\hline Lima, Peru & 1630-1702 & 33 & 409 & Parish Records \\
\hline Peru (Rural) & 1632 & 25 & 307 & Parish Records \\
\hline Lima, Peru & $1640-1680$ & 33 & 936 & Marriage Records \\
\hline Colombia & $1635-1695$ & 6 & 17 & Slave Inventories \\
\hline Guyane (French Guiana) & 1690 & 12 & 69 & Plantation Records \\
\hline Colombia & $1716-1725$ & 33 & 59 & Government Records \\
\hline French Louisiana & $1717-1769$ & 23 & 223 & Notarial Records \\
\hline Dominican Republic & $1717-1827$ & 11 & 15 & Government Records \\
\hline South Carolina & $1732-1775$ & 35 & 681 & Runaway Notices \\
\hline Colombia & $1738-1778$ & 11 & 100 & Various Records \\
\hline Spanish Louisiana & $1770-1803$ & 79 & 6,615 & Notarial Records \\
\hline St. Dominique (Haiti) & $1771-1791$ & 25 & 5,413 & Sugar Plantations \\
\hline Bahia, Brazil & $1775-1815$ & 14 & 581 & Slave Lists \\
\hline St. Dominique (Haiti) & $1778-1791$ & 36 & 1,280 & Coffee Plantations \\
\hline Guadeloupe & 1788 & 8 & 45 & Newspaper Reports \\
\hline St. Dominique (Haiti) & $1788-1790$ & 21 & 1,297 & Fugitive Slave Lists \\
\hline Cuba & $1791-1840$ & 59 & 3,093 & Slave Registers \\
\hline St. Dominique (Haiti) & $1796-1797$ & 56 & 5,632 & Plantation Inventories \\
\hline American Louisiana & $1804-1820$ & 62 & 223 & Notarial Records \\
\hline Salvador, Brazil & $1808-1842$ & 6 & 456 & Records of Manumission \\
\hline Trinidad & 1813 & 100 & 12,460 & Slave Registers \\
\hline St. Lucia & 1815 & 62 & 2,333 & Slave Registers \\
\hline Bahia, Brazil & $1816-1850$ & 27 & 2,666 & Slave Lists \\
\hline St. Kitts & 1817 & 48 & 2,887 & Slave Registers \\
\hline Senegal & 1818 & 17 & 80 & Captured Slave Ship \\
\hline Berbice (Guyana) & 1819 & 66 & 1,127 & Slave Registers \\
\hline Salvador, Brazil & $1819-1836$ & 12 & 871 & Manumission Certificates \\
\hline Salvador, Brazil & $1820-1835$ & 11 & 1,106 & Probate Records \\
\hline Sierra Leone & $1821-1824$ & 68 & 605 & Child Registers \\
\hline Rio de Janeiro, Brazil & $1826-1837$ & 31 & 772 & Prison Records \\
\hline Anguilla & 1827 & 7 & 51 & Slave Registers \\
\hline Rio de Janeiro, Brazil & $1830-1852$ & 190 & 2,921 & Free Africans' Records \\
\hline Rio de Janeiro, Brazil & $1833-1849$ & 35 & 476 & Death Certificates \\
\hline Salvador, Brazil & 1835 & 13 & 275 & Court Records \\
\hline Salvador, Brazil & $1838-1848$ & 7 & 202 & Slave Registers \\
\hline St. Louis/Goree, Senegal & $1843-1848$ & 21 & 189 & Emancipated Slaves \\
\hline Bakel, Senegal & 1846 & 16 & 73 & Sales Records \\
\hline d'Agoué, Benin & $1846-1885$ & 11 & 70 & Church Records \\
\hline Sierra Leone & 1848 & 132 & 12,425 & Linguistic and British Census \\
\hline Salvador, Brazil & $1851-1884$ & 8 & 363 & Records of Manumission \\
\hline Salvador, Brazil & $1852-1888$ & 7 & 269 & Slave Registers \\
\hline Cape Verde & 1856 & 32 & 314 & Slave Census \\
\hline Kikoneh Island, Sierra Leone & $1896-1897$ & 11 & 185 & Fugitive Slave Records \\
\hline
\end{tabular}




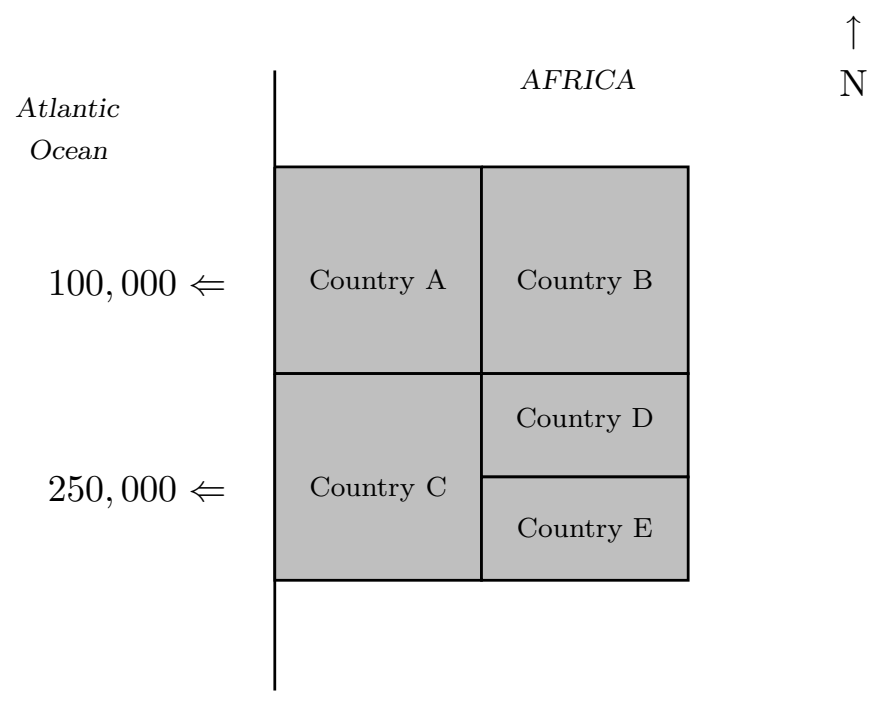

FIGURE I

An artificial map of the west coast of Africa

Because ethnicities tended to be much smaller than countries, the mapping of ethnicities into countries generally is not problematic. This is illustrated in Figure II, which shows African ethnicities based on Murdock's [1959] classification, as well as modern political boundaries. From the figure it is apparent that ethnicities are much smaller than modern boundaries, and therefore ethnicities generally map cleanly into one country. ${ }^{3}$

Assume that the ratio of slaves from Country A relative to Country B is 4 to 1 . This ratio suggests that $20 \%$ of the slaves shipped from Country A were actually from Country B. Therefore, the estimated number of slaves from Country B is 20,000 and from Country A is 80,000. Assume that the ratio of slaves from Country $\mathrm{C}$ to $\mathrm{D}$ to $\mathrm{E}$ is 3 to 1 to 1 . The same procedure then yields an estimate of 150,000 slaves from Country C and 50,000 each from Countries D and E. In practice, these calculation are performed separately for each slave trade. As well, because slaves were increasingly taken from further inland as each slave trade progressed, the calculations are also performed separately for each of the following time periods: 1400-

\footnotetext{
${ }^{3}$ In instances where an ethnicity is located in more than one country, I map the ethnicity into the multiple countries using land area as weights. This is explained in detail in Nunn [2007].
} 


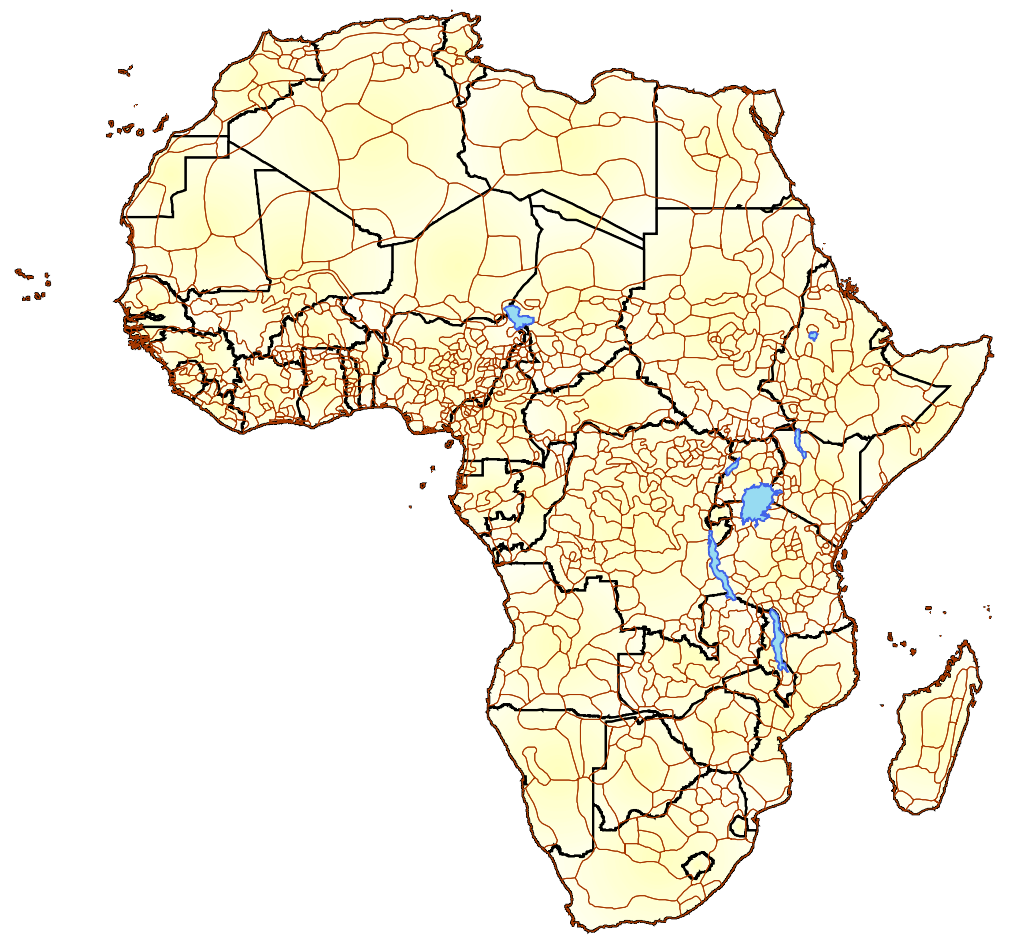

FIGURE II

Ethnic boundaries defined by Murdock [1959] and modern political boundaries

1599, 1600-1699, 1700-1799, 1800-1900. ${ }^{4}$

An important assumption in this procedure is that slaves shipped from a port within a country are either from that country or from countries directly to the interior. However, in reality, some slaves shipped from a country's coast may have originated from a neighboring coastal country. In Nunn [2007], using three samples of slaves for which we know both the ethnicity of the slaves and the port that they were shipped from, I test the validity of this assumption and the overall accuracy of the estimation procedure. I find that for each of the three samples my procedure correctly identifies the origins of between 83 and $98 \%$ of the slaves in the samples.

A second source of measurement error arises because slaves from the interior will tend to be under-represented in the ethnicity samples. This is

\footnotetext{
${ }^{4}$ See Nunn [2007] for all of the finer details of the construction procedure.
} 
because only slaves that survived the voyage outside of Africa are in the ethnicity samples. All else equal, the further inland a slave originated, the longer the journey was, and the more likely it was that he or she died along the way. Because the rates of mortality during the slave trades were extremely high, this form of measurement error may be significant. ${ }^{5}$ However, as I show formally in the Appendix, the under-sampling of slaves from the interior results in OLS estimates that are biased towards zero. As well, one can use instruments that are uncorrelated with the measurement error to derive consistent estimates. I do this in Section V.B.

After the data have been constructed, I have estimates of the number of slaves shipped from each country in Africa during each of the four slave trades during four different time periods: 1400-1599, 1600-1699, 1700-1799, 1800-1900. Table II reports the estimated total number of slaves exported from each country, as well as the total disaggregated by slave trade. Overall, the estimates are consistent with the general view among African historians of where the primary slaving areas were. During the trans-Atlantic slave trade, slaves were taken in greatest numbers from the 'Slave Coast' (Benin and Nigeria), West Central Africa (Zaire, Congo, and Angola), and the 'Gold Coast' (Ghana). All of these countries appear among the top exporting countries on the list. Ethiopia and Sudan are also among the top exporting countries because they were the primary suppliers of slaves shipped during the Red Sea and Saharan slave trades. The low number of slave exports from South Africa and Namibia confirms the view of African historians that these areas exported "virtually no slaves" [Manning, 1983, p. 839]. The relative magnitudes of exports from geographically close countries are also consistent with the qualitative evidence from the African history literature. Manning [1983, p. 839] writes that "some adjoining regions were quite dissimilar: Togo exported few slaves and the Gold Coast many; Gabon exported few slaves, and the Congo exported many." The estimates are consistent with Manning's observation. Exports from Togo are far less than from Ghana, and exports from Gabon are less than from the Republic of Congo.

\section{Basic Correlations: OLS Estimates}

I begin by examining the relationship between past slave exports and current economic performance. I normalize the total number of slaves taken

\footnotetext{
${ }^{5}$ Estimates of cross-Atlantic mortality rates ranged from 7 to $20 \%$ depending on the time period and the length of the voyage [Curtin, 1969, pp. 275-286; Lovejoy, 2000, p. 63]. Death rates during the trek to the coast are known with less certainty, but estimates range from 10 to 50\% [Lovejoy, 2000, pp. 63-64; Vansina, 1990, p. 218].
} 
TABLE II

Estimated TOTAL SLAVE EXPORTS BETWEen 1400 AND 1900 By COUNTRY

\begin{tabular}{|c|c|c|c|c|c|c|}
\hline Isocode & Country name & $\begin{array}{l}\text { Trans- } \\
\text { Atlantic }\end{array}$ & $\begin{array}{l}\text { Indian } \\
\text { Ocean }\end{array}$ & $\begin{array}{l}\text { Trans- } \\
\text { Saharan }\end{array}$ & $\begin{array}{r}\text { Red } \\
\text { Sea }\end{array}$ & $\begin{array}{r}\text { All slave } \\
\text { trades }\end{array}$ \\
\hline AGO & Angola & $3,607,020$ & 0 & 0 & 0 & $3,607,020$ \\
\hline NGA & Nigeria & $1,406,728$ & 0 & 555,796 & 59,337 & $2,021,859$ \\
\hline GHA & Ghana & $1,614,793$ & 0 & 0 & 0 & $1,614,793$ \\
\hline ETH & Ethiopia & 0 & 200 & 813,899 & 633,357 & $1,447,455$ \\
\hline SDN & Sudan & 615 & 174 & 408,261 & 454,913 & 863,962 \\
\hline MLI & Mali & 331,748 & 0 & 509,950 & 0 & 841,697 \\
\hline ZAR & Dem Rep of Congo & 759,468 & 7,047 & 0 & 0 & 766,515 \\
\hline MOZ & Mozambique & 382,378 & 243,484 & 0 & 0 & 625,862 \\
\hline TZA & Tanzania & 10,834 & 523,992 & 0 & 0 & 534,826 \\
\hline TCD & Chad & 823 & 0 & 409,368 & 118,673 & 528,862 \\
\hline BEN & Benin & 456,583 & 0 & 0 & 0 & 456,583 \\
\hline SEN & Senegal & 278,195 & 0 & 98,731 & 0 & 376,926 \\
\hline GIN & Guinea & 350,149 & 0 & 0 & 0 & 350,149 \\
\hline TGO & Togo & 289,634 & 0 & 0 & 0 & 289,634 \\
\hline GNB & Guinea-Bissau & 180,752 & 0 & 0 & 0 & 180,752 \\
\hline BFA & Burkina Faso & 167,201 & 0 & 0 & 0 & 167,201 \\
\hline MRT & Mauritania & 417 & 0 & 164,017 & 0 & 164,434 \\
\hline MWI & Malawi & 88,061 & 37,370 & 0 & 0 & 125,431 \\
\hline MDG & Madagascar & 36,349 & 88,927 & 0 & 0 & 125,275 \\
\hline $\mathrm{COG}$ & Congo & 94,663 & 0 & 0 & 0 & 94,663 \\
\hline KEN & Kenya & 303 & 12,306 & 60,351 & 13,490 & 86,448 \\
\hline SLE & Sierra Leone & 69,607 & 0 & 0 & 0 & 69,607 \\
\hline CMR & Cameroon & 66,719 & 0 & 0 & 0 & 66,719 \\
\hline DZA & Algeria & 0 & 0 & 61,835 & 0 & 61,835 \\
\hline CIV & Ivory Coast & 52,646 & 0 & 0 & 0 & 52,646 \\
\hline SOM & Somalia & 0 & 229 & 26,194 & 5,855 & 32,277 \\
\hline ZMB & Zambia & 6,552 & 21,406 & 0 & 0 & 27,958 \\
\hline GAB & Gabon & 27,403 & 0 & 0 & 0 & 27,403 \\
\hline GMB & Gambia & 16,039 & 0 & 5,693 & 0 & 21,731 \\
\hline NER & Niger & 133 & 0 & 0 & 19,779 & 19,912 \\
\hline LBY & Libya & 0 & 0 & 8,848 & 0 & 8,848 \\
\hline LBR & Liberia & 6,790 & 0 & 0 & 0 & 6,790 \\
\hline UGA & Uganda & 900 & 3,654 & 0 & 0 & 4,554 \\
\hline ZAF & South Africa & 1,944 & 87 & 0 & 0 & 2,031 \\
\hline $\mathrm{CAF}$ & Cen African Republic & 2,010 & 0 & 0 & 0 & 2,010 \\
\hline EGY & Egypt & 0 & 0 & 1,492 & 0 & 1,492 \\
\hline ZWE & Zimbabwe & 554 & 536 & 0 & 0 & 1,089 \\
\hline NAM & Namibia & 191 & 0 & 0 & 0 & 191 \\
\hline BDI & Burundi & 0 & 87 & 0 & 0 & 87 \\
\hline GNQ & Equatorial Guinea & 11 & 0 & 0 & 0 & 11 \\
\hline DJI & Djibouti & 0 & 5 & 0 & 0 & 5 \\
\hline BWA & Botswana & 0 & 0 & 0 & 0 & 0 \\
\hline $\mathrm{CPV}$ & Cape Verde Islands & 0 & 0 & 0 & 0 & 0 \\
\hline $\mathrm{COM}$ & Comoros & 0 & 0 & 0 & 0 & 0 \\
\hline LSO & Lesotho & 0 & 0 & 0 & 0 & 0 \\
\hline MUS & Mauritius & 0 & 0 & 0 & 0 & 0 \\
\hline MAR & Morocco & 0 & 0 & 0 & 0 & 0 \\
\hline RWA & Rwanda & 0 & 0 & 0 & 0 & 0 \\
\hline STP & Sao Tome \& Principe & 0 & 0 & 0 & 0 & 0 \\
\hline SWZ & Swaziland & 0 & 0 & 0 & 0 & 0 \\
\hline SYC & Seychelles & 0 & 0 & 0 & 0 & 0 \\
\hline TUN & Tunisia & 0 & 0 & 0 & 0 & 0 \\
\hline
\end{tabular}




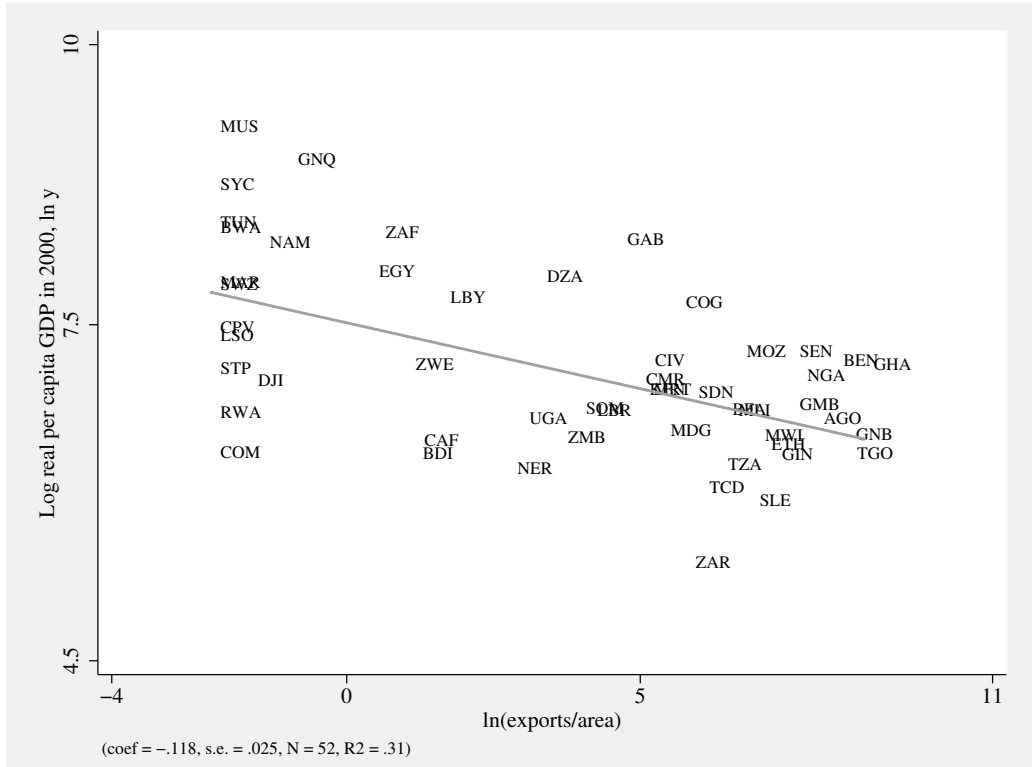

FIGURE III

Relationship between log slave exports normalized by land area, $\ln$ (exports/area), and log real per capita GDP in 2000, $\ln y$

from each country by its size, measured by land area. ${ }^{6}$ Figure III shows the relationship between the natural log of the number of slaves exported in all four slave trades between 1400 and 1900 normalized by land area, and the natural log of per capita GDP in $2000 .^{7}$ As shown in the figure, a negative relationship between income and slave exports is apparent in the raw data.

I further examine this relationship by controlling for other country characteristics that are also potentially important for current income. My baseline estimating equation is:

$$
\ln y_{i}=\beta_{0}+\beta_{1} \ln \left(\operatorname{exports}_{i} / \text { area }_{i}\right)+\mathbf{C}_{i}^{\prime} \delta+\mathbf{X}_{i}^{\prime} \gamma+\varepsilon_{i},
$$

where $\ln y_{i}$ is the natural log of real per capita GDP in country $i$ in 2000, and $\ln \left(\right.$ exports $_{i} /$ area $\left._{i}\right)$ is the natural log of the total number of slaves exported

\footnotetext{
${ }^{6}$ Alternative measures of country size are also possible. As I show in Table VI in the appendix, using the average population of a country between 1400 and 1900 yields nearly identical results. Similarly, using arable land area rather than land area also yields essentially identical results.

${ }^{7}$ Because the natural log of zero is undefined, I take the natural log of .1. As I show in the appendix, the results are robust to the omission of these zero export countries.
} 
between 1400 and 1900 normalized by land area. Per capita GDP data are for the year 2000 and are from Maddison [2003]. $\mathbf{C}_{i}$ is a vector of dummy variables that indicate the origin of the colonizer prior to independence. These are included to control for the other significant event in Africa's past, colonial rule. $\mathbf{X}_{i}$ is a vector of control variables that are meant to capture differences in countries' geography and climate.

OLS estimates of (1) are reported in Table III. The first column reports estimates of (1) with colonizer fixed effects only. In the second column, I also include controls that capture the potential importance of geography for long term economic development: distance from the equator, longitude, minimum monthly rainfall, average maximum humidity, average minimum temperature, and proximity to the ocean measured by the natural log of coastline divided by land area. All factors, except longitude, influence whether a country has a tropical climate, which affects the prevalence of infectious disease and agricultural productivity [Kamarck, 1976; Sachs et al., 2001]. Longitude is also included to capture differences between the Eastern and Western parts of the African continent. ${ }^{8}$ In both specifications, the estimated relationship between slave exports and per capita income are negative and statistically significant.

One concern with the estimates in columns 1 and 2 is that they may be biased because of the inclusion of small islands and North African countries in the sample. In column 3, I omit island and North African countries, dropping Morocco, Algeria, Tunisia, Libya, Egypt, Seychelles, Mauritius, Comoros, Sao Tome and Principe, and the Cape Verde Islands. As shown, dropping these countries makes little difference. The estimated coefficient for slave exports remains negative and significant, and the magnitude of the estimated coefficient actually increases. ${ }^{9}$

In column 4, I include additional control variables to account for potential differences between islands or North African countries and the rest of Africa. Two core differences between North Africa and the rest of Africa is that North African countries are predominantly Islamic and that they all have legal systems based on French civil law. To capture these differences,

\footnotetext{
${ }^{8} \mathrm{~A}$ related concern is that the slave exports variable may simply capture a West Africa fixed effect. I show in the appendix that the results are robust to also controlling for region fixed effects.

${ }^{9}$ One may also be concerned that the inclusion of the countries in Southern Africa - namely South Africa, Swaziland, and Lesotho - may also be biasing the results. As I report in the appendix, the results are robust to also omitting this group of countries. The table also shows that the estimates are robust to the omission of potentially influential observations.
} 
TABLE III

RELATIONSHIP BETWEEN SLAVE EXPORTS AND INCOME

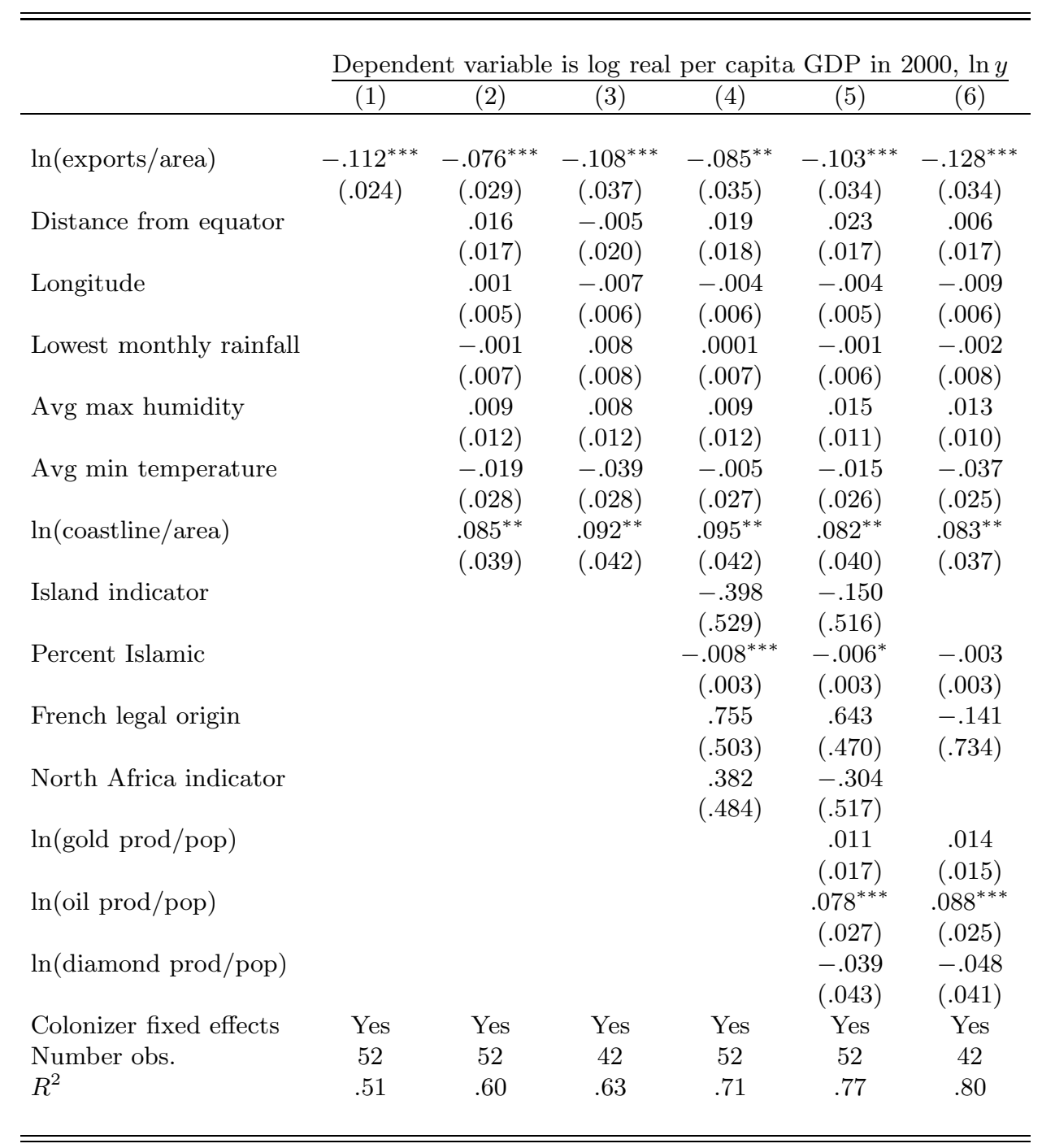

OLS estimates of (1) are reported. The dependent variable is the natural log of real per capita GDP in $2000, \ln y$. The slave export variable $\ln ($ exports/area) is the natural $\log$ of the total number of slaves exported from each country between 1400 and 1900 in the four slave trades normalized by land area. The colonizer fixed effects are indicator variables for the identity of the colonizer at the time of independence. Coefficients are reported with standard errors in brackets. ${ }^{* * *},{ }^{* *}$, and ${ }^{*}$ indicate significance at the 1,5 , and 10 percent levels. 
I also include a measure of the percent of the population that is islamic and a French legal origin indicator variable. I also include a North Africa fixed effect and an island fixed effect. As shown, including these additional control variables does not affect the slave exports coefficient, which remains negative and statistically significant.

The final factor that I control for are differences in countries endowments of natural resources. In column 5, I also control for the natural log of annual average per capita production between 1970 and 2000 of gold, oil, and diamonds. As shown, controlling for countries' production of these natural resources does not alter the results. ${ }^{10}$ In column 6 , I simultaneously include all control variables and drop islands and North African countries from the sample. Again the results remain robust. ${ }^{11}$

The estimated magnitudes of the relationship between slave exports and income are not only statistically significant but also economically meaningful. Calculating the standardized beta coefficients of the estimates, one finds that a one standard deviation increase in $\ln$ (exports/area) is associated with between .36 to .62 standard deviation decrease in log income. If for purely illustrative purposes one interprets the OLS estimates as causal, then according to the estimate from column 5 , for a country initially with the mean level of income of $\$ 1,249$, a one standard deviation decrease in the slave export variable will raise income to $\$ 1,864$, which is a $50 \%$ increase in income.

\section{Econometric Issues: Causality and Measurement Error}

Although the OLS estimates show that there is a relationship between slave exports and current economic performance, it remains unclear whether the slave trades have a causal impact on current income. An alternative explanation for the relationship is that societies that were initially underdeveloped selected into the slave trades, and these societies continue to be underdeveloped today. Therefore, we observe a negative relationship between slave exports and current income, even though the slave trades did not have any effect on subsequent economic development. In this section, I pursue two strategies to evaluate whether there is causal effect of the slave

\footnotetext{
${ }^{10}$ Looking at Figure III one can see that Equatorial Guinea (GNQ), which has a low value of slave exports and has recently witness extremely rapid economic growth because of the discovery of large offshore oil reserves, is a potential outlier. As I show in the appendix, the results are also robust to the omission of Equatorial Guinea from the sample.

${ }^{11}$ The island and North Africa indicator variables drop out of the equation when island and North African countries are omitted from the sample.
} 
trades on income. First, using historic data and qualitative evidence from African historians, I evaluate the importance and characteristics of selection into the slave trades. As I will show, the evidence suggests that selection was important, but it was usually the societies that were the most prosperous, not the most underdeveloped, that selected into the slave trades. Given this evidence, it is unlikely that the strong relationship between slave exports and current income is driven by selection. Instead, selection will tend to bias the OLS estimates towards zero. Second, I use the distance from each country to the location of the demand for slaves as instruments for slave exports. The IV results confirm the OLS estimates.

\section{V.A. Historical Evidence on Selection during the Slave Trades}

A large proportion of the early trade between Africans and Europeans was in commodities other than slaves. During this time, only societies with institutions that were sufficiently developed were able to facilitate trade with the Europeans. Between 1472 and 1483, the Portuguese sailed south along the West coast of Africa, testing various points of entry looking for trading partners. They were unable to find any societies north of the Zaire river that could support trade. Vansina [1990, p. 200] writes that "the local coastal societies were just too small in terms of people and territory; their economic and social institutions were too undifferentiated to facilitate foreign trade." Sustained trade did not occur until the Portuguese found the Kongo Kingdom, located just south of the Zaire river. Because the Kongo Kingdom had a centralized government, national currency, and welldeveloped markets and trading networks, it was able to support trade with the Europeans.

When European demand turned almost exclusively to slaves, the preference to trade with the most developed parts of Africa continued. Because the more prosperous areas were also the most densely populated, large numbers of slaves could be efficiently obtained if civil wars or conflicts could be instigated [Barry, 1992; Inikori, 2003]. As well, societies that were the most violent and hostile, and therefore least developed, were often best able to resist European efforts to purchase slaves. For example, the slave trade in Gabon was limited because of the defiance and violence of its inhabitants towards the Portuguese. This resistance continued for centuries, and as a result the Portuguese were forced to concentrate their efforts along the coast further south [Hall, 2005, pp. 60-64].

Using data on initial population densities, I check whether it was the more prosperous or less prosperous areas that selected into the slave trades. 


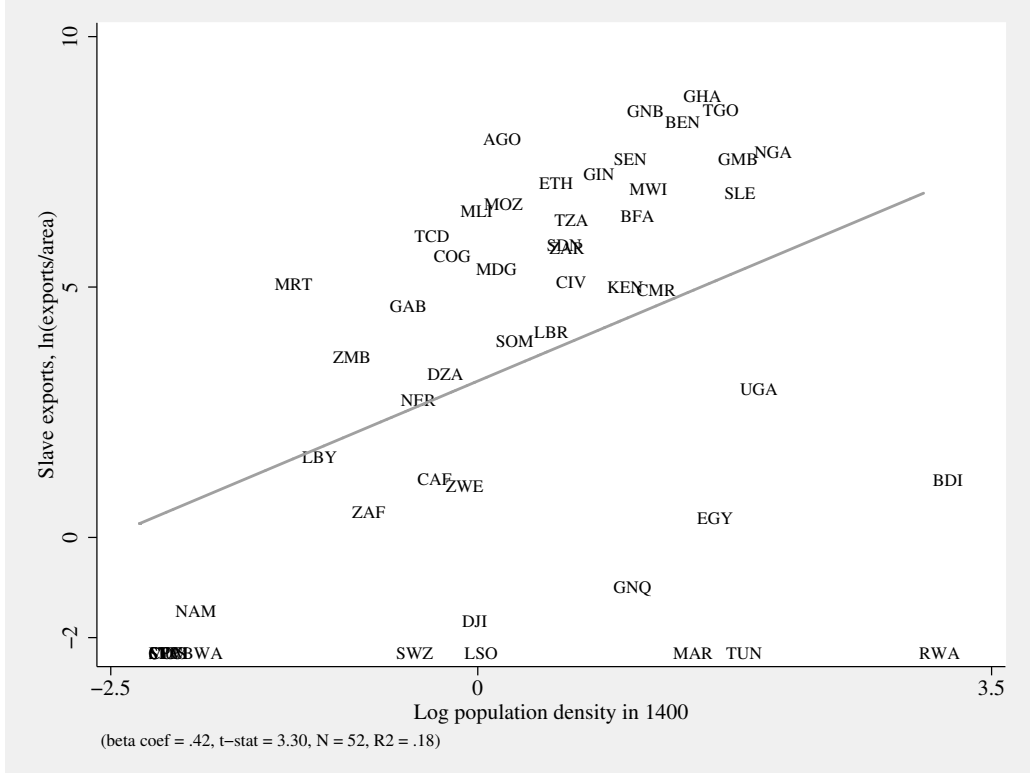

FIGURE IV

Relationship between initial population density and slave exports

Acemoglu et al. [2002] have shown that population density is a reasonable indicator of economic prosperity. Figure IV shows the relationship between the natural $\log$ of population density in 1400 and $\ln$ (exports/area). The data confirm the historical evidence on selection during the slave trades. ${ }^{12}$ The figure shows that the parts of Africa that were the most prosperous in 1400 , measured by population density, tend to also be the areas that were most impacted by the slave trades.

A second potential source of selection may be that societies that initially had domestic slavery may have selected into the slave trades. If this is the case, then the estimates may be biased by a negative relationship between domestic slavery and subsequent economic development, similar to that documented by Engerman and Sokoloff [1997, 2002] in the Americas.

The historic evidence indicates that in the areas of Africa that were part of the older Islamic slave trades there was domestic slavery, but it is unclear whether domestic slavery was a cause or a consequence of the external slave trades. Whether the parts of Africa that were untouched by the Islamic

\footnotetext{
${ }^{12}$ The relationship is similar if one excludes island and North African countries, or if one normalizes slave exports by population rather than land area.
} 
trades had chattel slavery prior to European contact has been the subject of an old debate among African historians [e.g., Fage, 1962; Rodney, 1970]. Since this debate evidence has been brought forth suggesting that domestic slavery may not have existed prior to the trans-Atlantic slave trade. Hilton [1985] provides evidence showing that in the sixteenth century, words that originally meant 'servant' or 'prisoner' were altered to take on the meaning of a 'traded slave'. Historian and Anthropologist Jan Vansina [1989], using more detailed linguistic data, confirms Hilton's finding, showing that in West Central Africa there was no word for slave. Vansina maps the origin of the word 'pika' which originally meant servant, but took on the meaning of a 'traded slave'. The word originated at the coastal ports engaged in the slave trade and spread to the inland communities that were also involved in the trade [Vansina, 1989, 1990]. Recent studies of other regions also suggest that prior to the external slave trade domestic slavery did not exist [e.g., Harms, 1981; Inikori, 2000; Hall, 2005, p. 16].

\section{V.B. Instrumental Variables}

The second strategy that I pursue is to use instruments that are correlated with slave exports, but are uncorrelated with other country characteristics. This strategy has the added benefit of yielding potentially consistent estimates even though slave exports are measured with error. If the instruments are also uncorrelated with the measurement error in slave exports that arises from the under-sampling of slaves from the interior, then unlike OLS, IV yields consistent estimates.

As instruments for slave exports, I use the distances from each African country to the locations of where slaves were demanded. The validity of the instruments relies on the presumption that although the location of demand influenced the location of supply, the location of supply did not influence the location of demand. If sugar plantations were established in the West Indies because the West Indies were close to the western coast of Africa, then the instruments are not valid. However, if instead many slaves were taken from Western Africa because it is relatively close to the plantation economies in the West Indies, then the instruments are potentially valid. According to the known history the slave trades, it was the location of demand that influenced the location of supply and not vice versa. The location of the demand for African slaves was determined by a number of factors, all unrelated to the supply of slaves. In the West Indies and the Southern United States, slaves were imported because of climates suitable for growing highly valued, globally traded commodities such as sugar and 
tobacco. The existence of gold and silver mines was a determinant of the demand for slaves in Brazil. In the Northern Sahara, Arabia and Persia, slaves were needed to work in salt mines, and in the Red Sea area slaves were used as pearl divers.

The instruments measure the distance from each country to the most important destinations in each of the slave trades. The four instruments are:

1. The sailing distance from the point on the coast that is closest to the country's centroid to the closest major market of the Atlantic slave trade. I use the nine largest importers of slaves, which are: Virginia, USA; Havana, Cuba; Haiti; Kingston, Jamaica; Dominica; Martinique; Guyana; Salvador, Brazil; and Rio de Janeiro, Brazil. ${ }^{13}$

2. The sailing distance from the point on the coast that is closest to the country's centroid to the closest of the two major slave destinations of the Indian Ocean slave trade: Mauritius and Muscat, Oman.

3. The overland distance from a country's centroid to the closest port of export for the trans-Saharan slave trade. The markets are: Algiers, Tunis, Tripoli, Benghazi and Cairo.

4. The overland distance from a country's centroid to the closest port of export for the Red Sea slave trade. The ports are: Massawa, Suakin, and Djibouti. ${ }^{14}$

The instruments are illustrated in Figure V, which shows the four distances for Burkina Faso. The ports in each of the four slave trades are represented by different colored symbols, and the shortest distances by colored lines. Details of the construction of the instruments are given in the appendix. $^{15}$

The IV estimates are reported in Table IV. The first column reports estimates without control variables, the second column includes colonizer

\footnotetext{
${ }^{13}$ Data on slave imports are from Eltis and Richardson [forthcoming]. There is a significant drop in the volume of slave imports between the 9th and 10th largest markets. Because of this natural break, I use the top 9 markets.

${ }^{14}$ For island countries, one cannot reach the ports of the Saharan or Red Sea slave trades by traveling overland. For these countries I use the sum of the sailing distance and overland distance.

${ }^{15} \mathrm{An}$ alternative strategy is to also include the distance from the centroid to the coast (which is also shown in Figure V) as an additional instrument since this distance is part of the total distance to the markets in the Indian Ocean and trans-Atlantic slave trades. The results are essentially identical if this distance is also included as an additional instrument.
} 


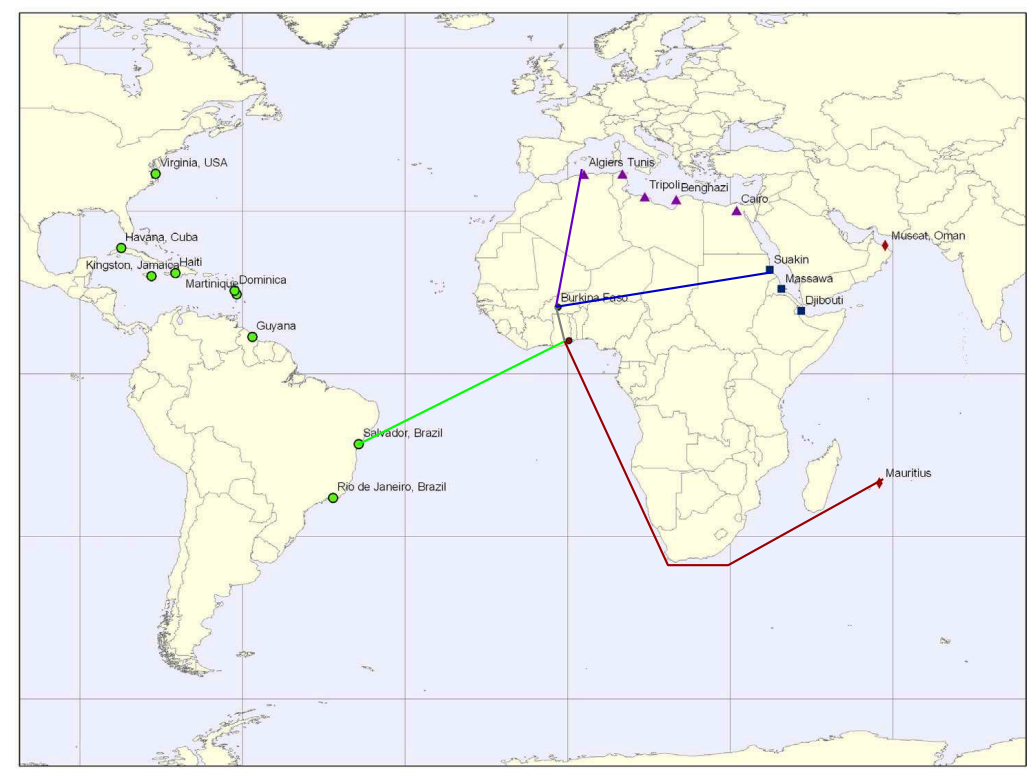

FIGURE V

Example showing the distance instruments for Burkina Faso

fixed effects, and the third and fourth columns include colonizer fixed effects and geography controls. In column 4, the sample excludes islands and North African countries.

The first stage estimates are reported in the bottom panel of the table. The coefficients for the instruments are generally negative, suggesting that the further a country was from slave markets, the less slaves it exported. ${ }^{16}$ The exception is the distance from the Red Sea ports, which is never significant, and even positive in one specification.

The second stage estimates are reported in the top panel. Because the first stage $F$-statistics are low, I also report conditional likelihood ratio (CLR) confidence intervals. The estimates for $\ln$ (exports/area) are all negative and statistically significant. In column 3 , the confidence interval is unbounded, which is a consequence of the low first stage $F$-statistic. The point estimates range from -.20 to -.28 . These magnitude are significantly larger than the magnitudes of the OLS estimates. This is not surprising

\footnotetext{
${ }^{16}$ The specifications assume a linear first stage relationship. The estimates are similar if one also allows for a non-linear relationship between slave exports and the distance instruments. The results are also similar if one uses the average or median distance to the ports in each trade, rather than the minimum distance.
} 
since the measurement error in the slave export estimates and the selection of the initially most prosperous societies into the slave trades are both expected to bias the OLS estimates towards zero.

A potential concern with the IV estimates is that the distances to the slave markets may be correlated with distances to other locations, which are important for economic development. The likelihood of this can be assessed by estimating the reduced form relationship between the distance instruments and income within Africa and outside of Africa. ${ }^{17}$ I find that within Africa, the four distance instruments are positively correlated with income, and all coefficients, except for the Red Sea coefficient, are highly significant. Begin further from slave markets was good for growth. However, outside of Africa, there is no clear relationship between the distance instruments and income. If the results of Table IV are driven by the relationship between the distances to slave markets and distances to other locations, then one would expect to also observe a positive relationship between the distance measures and income outside of Africa. However, this is not the case.

Overall, the IV results confirm the negative relationship between slave exports and income estimated by OLS. They also suggest that the OLS estimates may even be a lower bound estimate of the strength of the slave trade-income relationship.

\section{Possible Channels of Causality}

I now turn to the channels through which the slave trades may have affected economic development. I view this analysis as preliminary and exploratory. With only 52 observations it is not possible to pin down the precise channels and mechanism underlying the relationships with any reasonable degree of certainty. My strategy here is to simply investigate whether the data are consistent with the historic events described Section II.

An important consequence of the slave trades was that they tended to weaken ties between villages, thus discouraging the formation of larger communities and broader ethnic identities. I explore whether the data are consistent with this channel by examining the relationship between slave exports and a measure of current ethnic fractionalization from Alesina et al. [2003]. As shown in Figure VI, there is a strong positive relationship between the two variables. ${ }^{18}$ This is consistent with the historic accounts of the slave trades impeding the formation of broader ethnic identities.

This consequence of the slave trades is important because of the increas-

\footnotetext{
${ }^{17}$ I thank Ted Miguel for suggesting this check.

${ }^{18}$ The results are also similar if other measures of ethnic fractionalization are used.
} 
TABLE IV

IV ESTIMATES OF THE RELATIONSHIP BETWEEN SLAVE EXPORTS AND INCOME

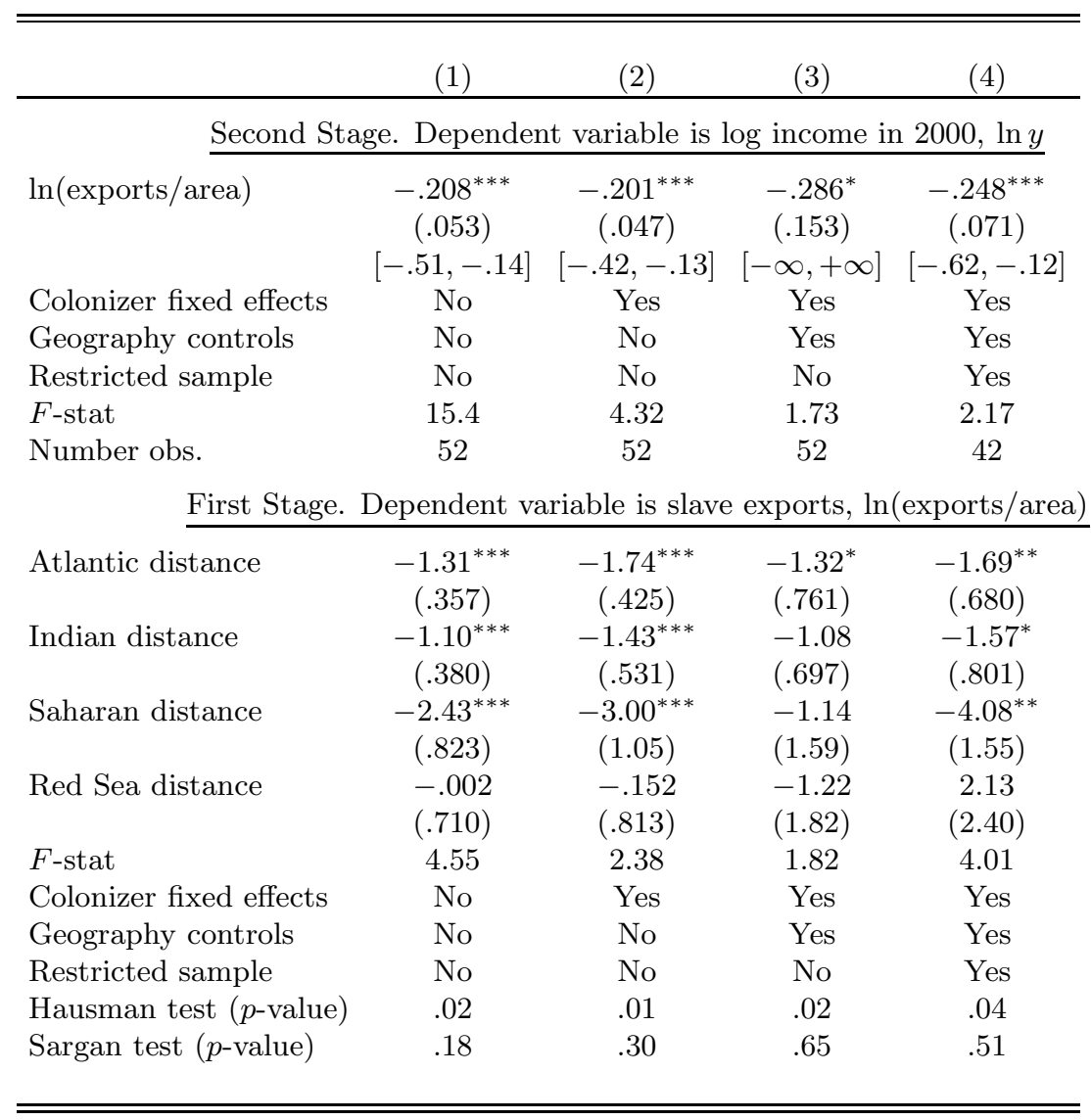

IV estimates of (1) are reported. Slave exports $\ln ($ exports/area) is the natural $\log$ of the total number of slaves exported from each country between 1400 and 1900 in the four slave trades normalized by land area. The colonizer fixed effects are indicator variables for the identity of the colonizer at the time of independence. Coefficients are reported, with standard errors in brackets. For the endogenous variable $\ln$ (exports/area), I also report 95 percent confidence regions based on Moreira's [2003] conditional likelihood ratio (CLR) approach. These are reported in square brackets. The $p$-value of the Hausman test is for the Wu-Hausman chi-squared test. ${ }^{* * *},{ }^{* *}$, and ${ }^{*}$ indicate significance at the 1,5 , and 10 percent levels. The 'restricted sample' excludes island and North African countries. The 'geography controls' are: distance from equator, longitude, lowest monthly rainfall, avg max humidity, avg min temperature, and $\ln$ (coastline/area). 


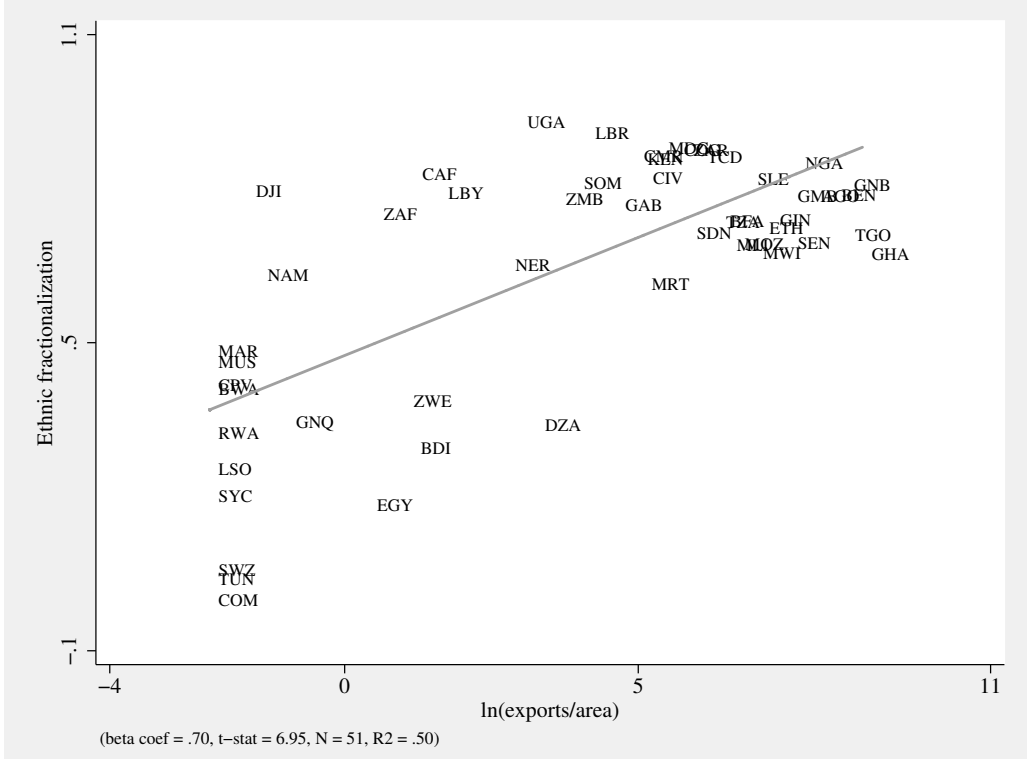

FIGURE VI

Relationship between slave exports and current ethnic fractionalization

ing evidence showing that ethnic fractionalization is an important determinant of a variety of factors necessary for economic development. Since the seminal article documenting the link between ethnic diversity and economic growth by Easterly and Levine [1997], subsequent research by La Porta et al. [1999], Alesina et al. [2003], Aghion et al. [2004], and Easterly et al. [2006] looks more deeply into why ethnic fractionalization is important for development. These studies find that ethnic diversity is important for social cohesion, domestic institutions, domestic polices, and the quality of government. As well, Alesina et al. [1999], Miguel and Gugerty [2005], and Banerjee and Somanathan [2006] find that ethnic fractionalization reduces the provision of public goods, such as education, health facilities, access to water, and transportation infrastructure, all of which are important for economic development.

A second, and closely related, consequence of the slave trades was the weakening and underdevelopment of states. To examine whether the data are consistent with this channel, I consider the relationship between slave exports and the level of state development following the slave trades. To do this I use a measure of pre-colonial state development from Gennaioli and Rainer [2006]. The measure is constructed using ethnographic data from Murdock 


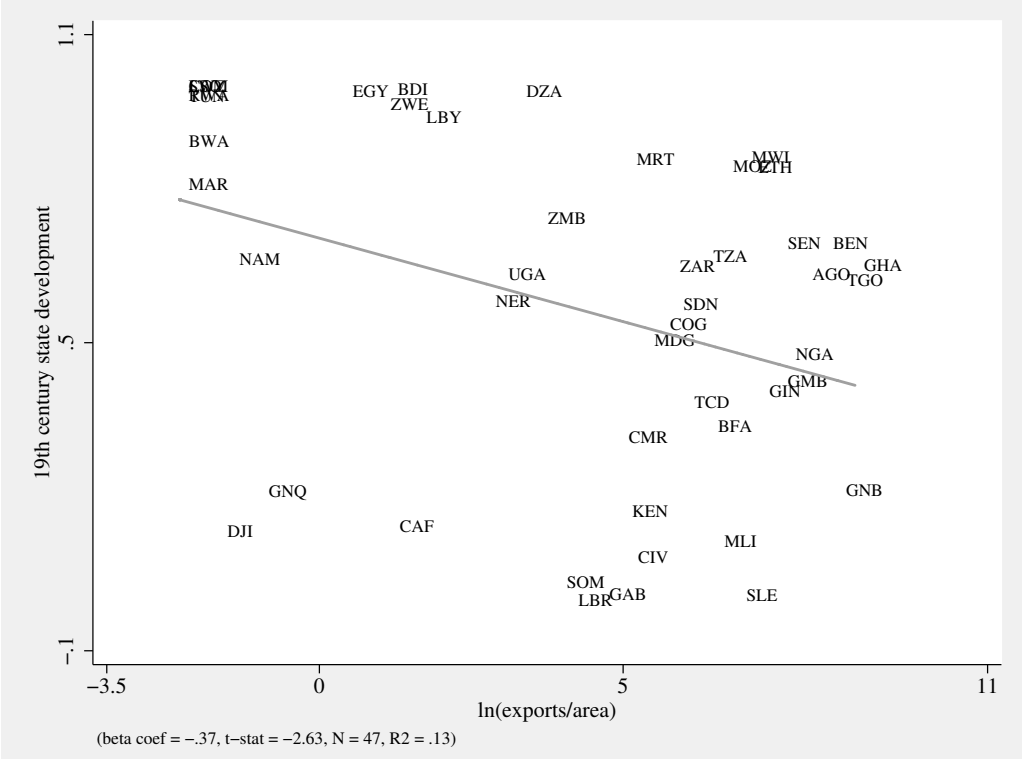

FIGURE VII

Relationship between slave exports and 19th century state development

[1967] on the indigenous political complexity of ethnic groups, measured by the number of jurisdictional hierarchies beyond the local community. The original measure ranges from 0 to 4 , with 0 indicating "stateless" societies and 4 indicating societies with "large states" [Murdock, 1967, p. 52]. Using this data, Gennaioli and Rainer [2006] construct a measure of the proportion of a country's indigenous population that belongs to an ethnic group that falls into category 2,3 , or 4 .

The relationship between slave exports and 19th century state development is shown in Figure VII. The negative relationship between slave exports and state centralization shown in the figure is consistent with the historic accounts of the slave trades causing long-term political instability, which resulted in weakened and fragmented states.

Recent empirical research shows that a country's history of state development is an important determinant of current economic performance. Bockstette et al. [2002] and Chanda and Putterman [2005] find that 'state antiquity', measured using an index of the depth of experience with statelevel institutions, is positively correlated with real per capita GDP growth between 1960 and 1995. Looking within Africa, Gennaioli and Rainer [2006] find that countries with ethnicities that had centralized pre-colonial state 


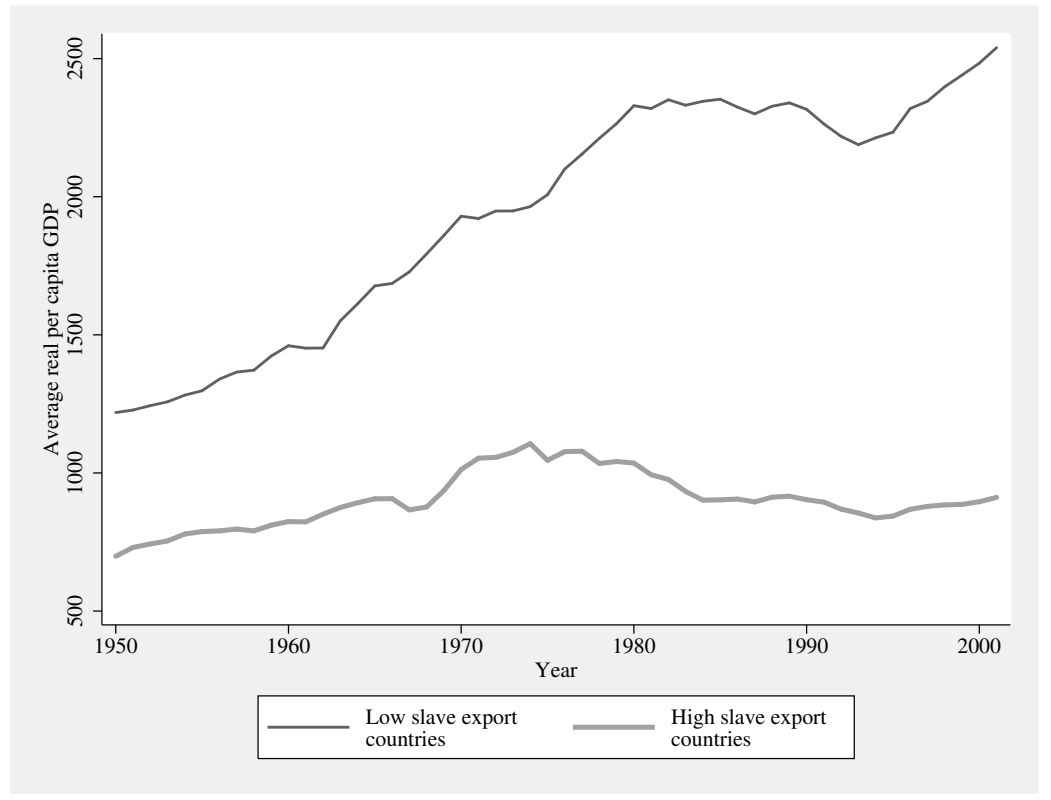

FIGURE VIII

Paths of economic development since 1950

institutions today provide more public goods, such as education, health, and infrastructure.

Herbst [1997, 2000] also focuses on the importance of state development for economic success, arguing that Africa's poor economic performance is a result of post-colonial state failure, the roots of which lie in the underdevelopment and instability of pre-colonial polities. Herbst [2000, chpt. 2-4] argues that because of a lack of significant political development during colonial rule, the limited pre-colonial political structures continued to exist after independence. ${ }^{19}$ As a result, Africa's post-independence leaders inherited nation states that did not have the infrastructure necessary to extend authority and control over the whole country. Many states were, and still are, unable to collect taxes from its citizens, and as a result they are also unable to provide a minimum level of public goods and services.

A corollary of Herbst's argument is that the impact of the slave trades may have been felt most strongly after colonial independence. This is because this is when pre-colonial political structures suddenly increased in im-

\footnotetext{
${ }^{19} \mathrm{On}$ the continuity between Africa's pre-colonial and post-colonial political systems also see Hargreaves [1969, p. 200].
} 
portance, as they became central determinants of the success of the newly formed state. Using Figure VIII, I examine whether the evolution of incomes since 1950 is consistent with this hypothesis. The figure shows average per capita GDP between 1950 and 2000 for two groups of African countries. $^{20}$ One group consists of the 26 countries with the lowest measures of $\ln$ (exports/area) and the other is the 26 countries with the highest measures of $\ln$ (exports/area). As shown in the figure, throughout the period low slave export countries are richer on average than high slave export countries. Also interesting, however, is the difference in the evolution of income between the two groups of countries. Although the low slave export countries were richer in the early 1950s when most countries were still under colonial rule, the income gap between the two groups increased significantly over time, and became most pronounced after the late 1960s and early 1970s when most countries had gained independence. ${ }^{21}$ This pattern is consistent with the slave trades affecting early state development, which may have mattered during colonial rule, but mattered much more after independence. Because those parts of Africa that were most severely impacted by the slave trades tended to have the least developed political systems, after independence these countries continued to have weak and unstable states, as well as slower economic growth.

\section{Conclusions}

Combining data from shipping records and data from historical documents reporting slave ethnicities, I have constructed estimates of the number of slaves exported from each country in Africa during Africa's four slave trades. I found a robust negative relationship between the number of slaves taken from a country and its subsequent economic development.

I pursued a number of strategies to better understand if the relationship is causal or spurious. If countries that were initially underdeveloped selected into the slave trades, and if these countries continue to be underdeveloped today, then this may explain the observed relationship between slave exports and current income. I first reviewed the historical evidence on the characteristics of African societies that were most affected by the slave trades. The qualitative and quantitative evidence show that it was actually

\footnotetext{
${ }^{20}$ The averages are weighted by each country's population in 2000.

${ }^{21}$ In 1950 only four African countries were independent. Ethiopia had never been colonized, and Liberia, South Africa, and Egypt had previously gained independence. By 1969, 42 of Africa's 52 countries had gained independence, and by 197648 countries were independent.
} 
the most developed parts of Africa, not the least developed, that tended to select into the slave trades. I also used the distances from each country to the locations of the demand for slaves as instruments to estimate the causal effect of the slave trades on economic development. The IV estimates confirmed the OLS results, suggesting that increased extraction during the slave trades resulted in worse economic performance.

I then examined the channels of causality underlying the relationship between slave exports and economic development. I showed that the data are consistent with historic accounts suggesting that the slave trades impeded the formation of broader ethnic groups, leading to ethnic fractionalization, and that the slave trades resulted in a weakening and underdevelopment of political structures.

\section{APPENDIX}

\section{A. Deriving the Bias from the Under-Sampling of Slaves from the Interior}

In this section I show that the under-sampling of slaves from the interior of Africa will result in OLS estimates of the effect of slave exports on income that are biased towards zero. To see this, denote the true number of slaves taken from country $i$ by $s_{i}^{*}$, the observed number of slaves by $s_{i}$, distance to the coast by $d_{i}$, and economic development by $y_{i}$. All variables are expressed as deviations from means. Assume the true relationship between the number of slaves exported and distance to the coast is given by

$$
s_{i}^{*}=-\alpha d_{i}+\varepsilon_{i},
$$

where $\alpha>0$ and $\varepsilon_{i}$ is i.i.d. drawn from a normal distribution. The relationship between the observed number of slaves exported $s_{i}$ and the distance to the coast $d_{i}$ is given by

$$
s_{i}=s_{i}^{*}-\gamma d_{i}+\nu_{i},
$$

where $\gamma>0$ and $\nu_{i}$ is uncorrelated with $\varepsilon_{i}$. The true relationship between slave exports and development is given by

$$
y_{i}=-\beta s_{i}^{*}+\omega_{i}
$$

where $\beta>0$ and $\omega_{i}$ is uncorrelated with all other variables.

If one estimates $y_{i}=b s_{i}+\xi_{i}$ by OLS, then the estimated relationship between $s_{i}$ and $y_{i}$ is

$$
\hat{b}=\frac{\sum_{i} s_{i} y_{i}}{\sum_{i} s_{i}^{2}}
$$


Substituting (2) into (3) gives

$$
s_{i}=-(\alpha+\gamma) d_{i}+\varepsilon_{i}+\nu_{i} .
$$

Similarly, (2) and (4) give

$$
y_{i}=\beta \alpha d_{i}-\beta \varepsilon_{i}+\omega_{i}
$$

Substituting (6) and (7) into (5), and taking the plim of $\hat{b}$ gives

$$
\operatorname{plim} \hat{b}=-\beta\left[\frac{\sigma_{s^{*}}^{2}+\gamma \alpha \sigma_{d}^{2}}{\sigma_{s^{*}}^{2}+2 \gamma(\alpha+\gamma) \sigma_{d}^{2}+\sigma_{\nu}^{2}}\right],
$$

where $\sigma_{s^{*}}^{2}=\alpha^{2} \sigma_{d}^{2}+\sigma_{\varepsilon}^{2}$.

First, consider the case when the only source of measurement error is classical measurement error. Then $\gamma=0$ and (8) reduces to the standard formula for attenuation bias: $\operatorname{plim} \hat{b}=-\beta\left[\sigma_{s^{*}}^{2} /\left(\sigma_{s^{*}}^{2}+\sigma_{\nu}^{2}\right)\right]$.

Next, consider the measurement error introduced by the under-sampling of slaves from the interior. The result of this is that the under-estimation of slave exports is increasing in a country's distance from the coast: $\gamma>0$. Looking at (8), it is apparent that $2 \gamma(\alpha+\gamma)>\gamma \alpha$ and therefore the presence of non-classical measurement error also biases the estimated coefficient towards zero, reinforcing the attenuation bias resulting from classical errorsin-variables.

\section{B. Data}

Real per capita GDP data are from Maddison [2003]. Land area, which is used to calculate $\ln$ (export/area), $\ln$ (coastline/area), and population density in 1400, is measured in millions of square kilometers, and is from Parker [1997]. Historic population figures, measured in thousands of people, are from McEvedy and Jones [1978]. For some groups of the smaller countries, population data are only disaggregated to a regional level. In these cases the data are disaggregated to the country level using the distribution of population in 1950 from the United Nations. Data on the identity of the colonizer before independence are from the Political Regimes and Regime Transitions in Africa, 1910-1994 data set, which is described in [Bratton and van de Walle, 1997].

Distance from the equator is the absolute value of the latitude of each country's centroid, measured in degrees. Longitude is the longitude of each countries centroid also measured in degrees. The centroid of each country is calculated using the Centroid Utility in ArcGIS. For five countries where 
the centroid falls outside the land borders of the country (Gambia, Somalia, Cape Verde, Mauritius and Seychelles) the point within the country closest to the centroid is used. The location on the coast that is closest to each country's centroid is identified using the Proximity Utility in ArcGIS.

Lowest monthly rainfall is the average total rainfall, measured in millimeters, in the driest month of the year. Average maximum humidity is the average of the maximum afternoon humidity, measured in percent, during the hottest month of the year. Average minimum temperature is the lowest average monthly temperature measured in degrees Celsius. The data are from meteorological data taken over a 30 year period and reported in Parker [1997]. Countries' total coastline, which is used along with land area to calculate $\ln$ (coastline/area) is measured in thousands of kilometers, and is from Parker [1997].

The percent Islamic variable is the percent of a country's population that is Islamic. The data are from Parker [1997]. Data on countries' legal origins are from La Porta et al. [1999]. All countries in the sample are coded as being either British common law or French civil law countries. Data on the production of diamonds, crude petroleum, and mined gold are from the British Geological Survey's World Mineral Statistics and World Mineral Production. All three variables are measured as the natural log of the average annual production per thousand inhabitants from 1970 to 2000. Diamonds include both gemstones and industrial diamonds and are measured in thousands of carats. Crude Petroleum is measured in thousands of tonnes, and mined gold is measured in kilograms.

Ethnic fractionalization is from Alesina et al. [2003]. The measure of 19th century state development is from Gennaioli and Rainer [2006].

When taking the natural log of variables that may take on the value of zero, I replace the zero observations with $1 \times 10^{n}$, where $n$ is the largest integer value possible subject to $1 \times 10^{n}$ being less than the smallest non-zero observation in the data.

The distance instruments measure the shortest sailing distances to the location of demand in the trans-Atlantic and Indian Ocean slave trades, and the shortest overland distance to the locations of demand in the Red Sea and trans-Saharan slave trades. The distances are calculated using the great circle distance between two locations. The formula for this is: $d_{i j}=$ $\left(\arccos \left\{\sin \left(L a_{i}\right) \sin \left(L a_{j}\right)+\cos \left(L a_{i}\right) \cos \left(L a_{j}\right) \cos \left(L o_{i}-L o_{j}\right)\right\} \times 111.12\right) / 1000$, where $d_{i j}$ is the distance in thousands of kilometers between location $i$ and $j$, $L a_{i}$ is the latitude of location $i$ in degrees, and $L o_{i}$ is the longitude of location $i$ in degrees. When calculating the sailing distances, I do not allow ships to sail across land or through the Suez Canal, which was not completed 
until 1869. For voyages from Northern Africa in the trans-Atlantic slave trade, I calculate the sailing distance through the Strait of Gibraltar to the closest market in the Atlantic Ocean. For the distance from these countries in the Indian Ocean slave trade, I calculate the sailing distance through the Mediterranean sea, and then south around the Cape of Good Hope. When calculating distances from East African countries during the trans-Atlantic slave trade, and from West African countries during the Indian Ocean slave trade, I calculate the sailing distance around the Cape of Good Hope.

Department of Economics, University of British Columbia and the Canadian Institute for Advanced Research (CIFAR) 


\section{B. Appendix Tables}

TABLE V

SUMmaRY STATISTICS

\begin{tabular}{lrrrrr}
\hline \hline & & & & & \\
Variable & Mean & Std dev & Min & Max & N \\
\hline & & & & & \\
ln real per capita GDP in 2000 & 7.13 & .83 & 5.38 & 9.27 & 52 \\
$\ln$ (exports/area) & 3.26 & 3.89 & -2.30 & 8.82 & 52 \\
$\ln ($ exports/pop) & 9.26 & 3.68 & 3.91 & 14.4 & 52 \\
Distance from equator & 13.6 & 9.86 & .2 & 36 & 52 \\
Longitude & 16.7 & 20.2 & -24.0 & 57.8 & 52 \\
Lowest monthly rainfall & 8.87 & 16.1 & 0 & 69 & 52 \\
Avg max humidity & 71.7 & 11.9 & 35 & 95 & 52 \\
Avg min temperature & 8.75 & 7.49 & -9.0 & 19 & 52 \\
$\ln ($ coastline/area) & -.24 & 3.24 & -4.61 & 6.98 & 52 \\
Island indicator & .10 & .30 & 0 & 1 & 52 \\
Percent Islamic & 35.3 & 39.1 & 0 & 100 & 52 \\
French legal origin & .65 & .48 & 0 & 1 & 52 \\
North Africa indicator & .10 & .30 & 0 & 1 & 52 \\
$\ln$ (gold prod/pop) & -7.48 & 5.66 & -13.8 & 3.08 & 52 \\
$\ln ($ oil prod/pop) & -6.71 & 4.03 & -9.21 & 3.24 & 52 \\
$\ln ($ diamond prod/pop) & -5.49 & 2.40 & -6.91 & 2.19 & 52 \\
Atlantic distance & 7.38 & 3.28 & 3.64 & 16.4 & 52 \\
Indian distance & 6.93 & 4.24 & .032 & 16.8 & 52 \\
Saharan distance & 3.51 & 1.57 & .308 & 6.64 & 52 \\
Red Sea distance & 3.44 & 1.47 & .064 & 6.47 & 52 \\
& & & & & \\
\hline \hline
\end{tabular}


TABLE VI

ROBUSTNESS AND SENSITIVITY CHECKS

\begin{tabular}{lcccc}
\hline \hline Specification: & Coef & Std Err & $\mathrm{N}$ & $R^{2}$ \\
\hline $\begin{array}{l}\text { Normalizing slave exports by average } \\
\text { population from } 1400 \text { to } 1900\end{array}$ & $-.103^{* * *}$ & $(.035)$ & 52 & .77 \\
Omitting zero slave export countries & $-.104^{* *}$ & $(.041)$ & 41 & .84 \\
Omitting N. Africa, islands, & $-.140^{* * *}$ & $(.040)$ & 38 & .70 \\
GNQ, LSO, SWZ, and ZAF & & & & \\
Including five region fixed effects & $-.099^{* *}$ & $(.036)$ & 52 & .80 \\
Omitting influential observations & $-.091^{* * *}$ & $(.031)$ & 42 & .90 \\
& & & & \\
\hline \hline
\end{tabular}

The table reports OLS estimates of (1), with the full set of control variables from Table III included. The dependent variable is the natural log of real per capita GDP in 2000, $\ln y$. Each row of the table reports estimates from one regression. ${ }^{* * *},{ }^{* *}$, and ${ }^{*}$ indicate significance at the 1,5 , and 10 percent levels. The 'five region fixed effects' in row 4 are North, West, Central, East, and South Africa. In row 5 , influential observations were omitted if Cook's distance was greater than $4 / N$, where $N$ is the number of observations. 


\section{References}

Acemoglu, Daron, Simon Johnson, and James A. Robinson, "The Colonial Origins of Comparative Development: An Empirical Investigation," American Economic Review, XCI (2001), 1369-1401.

, "Reversal of Fortune: Geography and Institutions in the Making of the Modern World Income Distribution," Quarterly Journal of Economics, CXVII (2002), 12311294.

Aghion, Philippe, Alberto Alesina, and Francesco Trebbi, "Endogenous Political Institutions," Quarterly Journal of Economics, CXIX (2004), 565-613.

Alesina, Alberto, Reza Baquir, and William Easterly, "Public Goods and Ethnic Divisions," Quarterly Journal of Economics, CXIV (1999), 1243-1284.

Alesina, Alberto, Arnaud Devleeschauwer, William Easterly, Sergio Kurlat, and Romain Wacziarg, "Fractionalization," Journal of Economic Growth, VIII (2003), 155-194.

Alpers, Edward A., "Trade, State, and Society among the Yao in the Nineteenth Century," The Journal of African History, X (1969), 405-420.

—, Ivory and Slaves in East Central Africa (Heinemann International, London, 1975).

Austen, Ralph A., "The Trans-Saharan Slave Trade: A Tentative Census," in Henry A. Gemery and Jan S. Hogendorn, eds., The Uncommon Market: Essays in the Economic History of the Atlantic Slave Trade (Academic Press, New York, 1979), 23-75.

- "The 19th Century Islamic Slave Trade from East Africa (Swahili and Red Sea Coasts): A Tentative Census," Slavery $\&$ Abolition, IX (1988), 21-44.

- "The Mediterranean Islamic Slave Trade out of Africa: A Tentative Census," Slavery \& Abolition, XIII (1992), 214-248.

Azevedo, Mario, "Power and Slavery in Central Africa: Chad (1890-1925)," Journal of Negro History, LXVII (1982), 198-211.

Bairoch, Paul, Economics and World History: Myths and Paradoxes (University of Chicago Press, Chicago, 1993).

Banerjee, Abhijit, and Rohini Somanathan, "The Political Economy of Public Goods: Some Evidence from India," (2006), mimeo.

Barry, Boubacar, "Senegambia from the Sixteenth to the Eighteenth Century: Evolution of the Wolof, Sereer, and 'Tukuloor'," in B.A. Ogot, ed., General History of Africa: Volume 5, Africa from the Sixteenth to the Eighteenth Century (University of California Press, Berkeley, 1992), 262-299.

, Senegambia and the Atlantic Slave Trade (Cambridge University Press, Cambridge, U.K., 1998). 
Bertocchi, Graziella, and Fabio Canova, "Did Colonization Matter for Growth? An Empirical Exploration into the Historical Causes of Africa's Underdevelopment," European Economic Review, XLVI (2002), 1851-1871.

Bockstette, Valeri, Areendam Chanda, and Louis Putterman, "States and Markets: The Advantage of an Early Start," Journal of Economic Growth, VII (2002), 347-369.

Bratton, Michael, and Nicolas van de Walle, "Political Regimes and Regime Transitions in Africa, 1910-1994," Technical Report 6996, ICPSR (1997).

Chanda, Areendam, and Louis Putterman, "State Effectiveness, Economic Growth, and the Age of States," in Matthew Lange and Dietrich Rueschemeyer, eds., States and Development: Historical Antecedents of Stagnation and Advance (Palgrave MacMillan, New York, 2005), 69-91.

Colson, Elizabeth, "African Society at the Time of the Scramble." in L.H. Gann and Peter Duignan, eds., Colonialism in Africa, 1870-1960. Volume 1: The History and Politics of Colonialism, 1870-1914. (Cambridge University Press, Cambridge, 1969), 27-65.

Curtin, Philip D., The Atlantic Slave Trade: A Census (The University of Wisconsin Press, Madison, 1969).

Easterly, William, and Ross Levine, "Africa's Growth Tragedy: Policies and Ethnic Divisions," Quarterly Journal of Economics, CXII (1997), 1203-1250.

Easterly, William, Jozef Ritzan, and Michael Woolcock, "Social Cohesion, Institutions, and Growth," Working Paper 94, Center for Global Development (2006).

Elbl, Ivana, "Volume of the Early Atlantic Slave Trade, 1450-1521," Journal of African History, XXXVIII (1997), 31-75.

Eltis, David, Stephen D. Behrendt, David Richardson, and Herbert S. Klein, The TransAtlantic Slave Trade: A Database on CD-Rom (Cambridge University Press, New York, 1999).

Eltis, David, and David Richardson, "Missing Pieces and the Larger Picture: Some Implications of the New Database," in David Eltis and David Richardson, eds., The New Transatlantic Slave Trade Database: Missing Pieces and Fresh Perspectives (forthcoming).

Engerman, Stanley L., and Kenneth L. Sokoloff, "Factor Endowments, Institutions, and Differential Paths of Growth Among New World Economies: A View from Economic Historians of the United States," in Stephen Harber, ed., How Latin America Fell Behind (Stanford University Press, Stanford, 1997), 260-304.

_ - "Factor Endowments, Inequality, and Paths of Development Among New World Economies," Working Paper 9259, National Bureau of Economic Research (2002).

Englebert, Pierre, "Pre-Colonial Institutions, Post-Colonial States, and Economic Development in Tropical Africa," Political Research Quarterly, LIII (2000a), 7-36. 
, "Solving the Mystery of the Africa Dummy," World Development, XXVIII (2000b), 1821-1835.

Fage, John D., An Introduction to the History of West Africa, 3rd ed. (Cambridge University Press, Cambridge, 1962).

Gennaioli, Nicola, and Ilia Rainer, "The Modern Impact of Precolonial Centralization in Africa," (2006), mimeo, Stockholm University.

Grier, Robin M., "Colonial Legacies and Economic Growth," Public Choice, XCVIII (1999), 317-335.

Hall, Gwendolyn Midlo, Slavery and African Ethnicities in the Americas: Restoring the Links (University of North Carolina Press, Chapel Hill, 2005).

Hargreaves, John D., "West African States and the European Conquest," in L.H. Gann and Peter Duignan, eds., Colonialism in Africa, 1870-1960 (Cambridge University Press, Cambridge, 1969), 199-219.

Harms, Robert, River of Wealth, River of Sorrow: The Central Zaire Basin in the Era of the Slave and Ivory Trade, 1500-1891 (Yale University Press, New Haven, 1981).

Hawthorne, Walter, "The Production of Slaves Where There was no State: The GuineaBissau Region, 1450-1815," Slavery \& Abolition, XX (1999), 97-124.

- Planting Rice and Harvesting Slaves: Transformations along the Guinea-Bissau Coast, 1400-1900 (Heinemann, Portsmouth, NH, 2003).

Herbst, Jeffrey, "Responding to State Failure in Africa," International Security, XXI (1997), 120-144.

—, States and Power in Africa (Princeton University Press, Princeton, 2000).

Higman, Barry W., Slave Populations of the British Caribbean, 1807-1834 (The John Hopkins University Press, Baltimore, 1984).

Hilton, Anne, The Kingdom of Kongo (Claredon, Oxford, 1985).

Hubbell, Andrew, "A View of the Slave Trade from the Margin: Souroudougou in the Late Nineteenth-Century Slave Trade of the Niger Bend," Journal of African History, XLII (2001), 25-47.

Inikori, Joseph E., "Africa and the Trans-Atlantic Slave Trade," in Toyin Falola, ed., Africa Volume I: African History Before 1885 (Carolina Academic Press, North Carolina, 2000), 389-412.

, "The Struggle against the Trans-Atlantic Slave Trade," in A. Diouf, ed., Fighting the Slave Trade: West African Strategies (Ohio University Press, Athens, Ohio, 2003), $170-198$.

Isaacman, Allen F., "The Countries of the Zambezi Basin," in J.F.A. Ajayi, ed., General History of Africa, VI (Heinemann International, Paris, 1989), 179-210. 
Kamarck, Andrew M., The Tropics and Economic Development (John Hopkins University Press, Baltimore, MD, 1976).

Karasch, Mary C., Slave Life in Rio de Janeiro (Princeton University Press, Princeton, NJ, 1987).

Kimambo, I.N., "The East African Coast and Hinterland, 1845-1880," in J.F.A. Ajayi, ed., General History of Africa, VI (Heinneman International, Paris, 1989), 234-269.

Klein, Martin, "The Slave Trade and Decentralized Societies," Journal of African History, XLII (2001), 49-65.

Koelle, Sigismund Wilhelm, Polyglotta Africana; or A Comparative Vocabulary of Nearly Three Hundred Words and Phrases, in More than One Hundred Distinct African Languages (Church Missionary House, London, 1854).

Kusimba, Chapurukha M., "Archaeology of Slavery in East Africa," African Archaeological Review, XXI (2004), 59-88.

La Porta, Rafael, Florencio Lopez-de-Silanes, Andrei Shleifer, and Robert W. Vishny, "The Quality of Government," Journal of Law, Economics, and Organization, XV (1999), 222-279.

Lagerlöf, Nils-Petter, "Geography, Institutions and Growth: The United States as a Microcosm," (2005), mimeo, York University.

Lange, Matthew K., "British Colonial Legacies and Political Development," World Development, XXXII (2004), 905-922.

Lovejoy, Paul E., "Background to Rebellion: The Origins of Muslim Slaves in Bahia," Slavery $\&$ Abolition, XV (1994), 151-180.

, Transformations in Slavery: A History of Slavery in Africa, Second Edition (Cambridge University Press, Cambridge, UK, 2000).

Maddison, Angus, The World Economy: Historical Statistics (Organisation for Economic Co-operation and Development, Paris, 2003).

Mahadi, Abdullahi, "The Aftermath of the Jihād in the Central Sudan as a Major Factor in the Volume of the Trans-Saharan Slave Trade in the Nineteenth Century," in Elizabeth Savage, ed., The Uncommon Market: Essays in the Economic History of the Atlantic Slave Trade (Frank Cass, London, 1992), 111-128.

Manning, Patrick, "Contours of Slavery and Social Change in Africa," American Historical Review, LXXXVIII (1983), 835-857.

— Slavery and African Life (Cambridge University Press, Cambridge, UK, 1990).

Mbajedwe, Patrick U., "Africa and the Trans-Atlantic Slave Trade," in Toyin Falola, ed., Africa Volume I: African History Before 1885 (Carolina Academic Press, North Carolina, 2000), 335-358. 
McEvedy, Colin, and Richard Jones, Atlas of World Population History (Penguin Books, Harmondsworth, 1978).

Miguel, Edward, and Mary Kay Gugerty, "Ethnic Diversity, Social Sanctions, and Public Goods in Kenya," Journal of Public Economics, LXXXIX (2005), 2325-2368.

Mitchener, Kris James, and Ian W. McLean, "The Productivity of U.S. States Since 1880," Journal of Economic Growth, VIII (2003), 73-114.

Moreira, Marcelo J., "A Conditional Likelihood Ratio Test for Structural Models," Econometrica, LXXI (2003), 1027-1048.

Moreno Fraginals, Manuel, "Africa in Cuba: A Quantitative Analysis of the African Population in the Island of Cuba," in Vera Rubin and Arthur Truden, eds., Comparative Perspectives on Slavery in New World Plantation Societies (New York Academy of Sciences, New York, 1977), 187-201.

Murdock, George Peter, Africa: Its Peoples and Their Cultural History (McGraw-Hill Book Company, New York, 1959).

— Ethnographic Atlas (University of Pittsburgh Press, Pittsburgh, 1967).

Northrup, David, Trade Without Rulers: Pre-Colonial Economic Development in SouthEastern Nigeria (Claredon Press, Oxford, 1978).

Nunn, Nathan, "Data Appendix for The Long-Term Effects of Africa's Slave Trades," (2007), mimeo, University of British Columbia.

Oldendorp, Christian Georg Andreas, C.G.A. Oldendorp's History of the Mission of the Evangelical Brethren on the Caribbean Islands of St. Thomas, St. Croix, and St. John (Reprinted by Karoma Publishers Inc. in 1987, Ann Arbor, 1777).

Parker, Philip M., National Cultures of the World: A Statistical Reference (Greenwood Press, London, 1997).

Rodney, Walter, A History of the Upper Guinea Coast (Clarendon Press, Oxford, 1970).

Sachs, Jeffrey D., Andrew D. Mellinger, and John L. Gallup, "The Geography of Poverty and Wealth," Scientific American, CCLXXXIV (2001), 70-76.

Tardieu, Jean-Pierre, "Origins of the Slaves in the Lima Region in Peru (Sixteenth and Seventeenth Centuries)," in Doudou Diene, ed., From Chains to Bonds: The Slave Trade Revisited (2001), 43-55.

Vansina, Jan, Kingdoms of the Savanna (University of Wisconsin Press, Madison, 1966).

— (1989), 341-362.

Paths in the Rainforests (The University of Wisconsin Press, Wisconsin, 1990).

Wax, Darold D., "Preferences for Slaves in Colonial America," Journal of Negro History, LVIII (1973), 371-401. 